\title{
Hematopoietic stem cell specific V-ATPase controls breast cancer progression and metastasis via cytotoxic $\mathrm{T}$ cells
}

\author{
Manoranjan Sahoo ${ }^{1}$, Gajendra K. Katara ${ }^{1}$, Mahmood Y. Bilal ${ }^{1}$, Safaa A. Ibrahim ${ }^{1}$, \\ Arpita Kulshrestha ${ }^{1}$, Sara Fleetwood ${ }^{1}$, Kimiko Suzue ${ }^{2}$ and Kenneth D. Beaman ${ }^{1}$ \\ ${ }^{1}$ Department of Microbiology and Immunology, Chicago Medical School, Rosalind Franklin University of Medicine and Science, \\ North Chicago, IL, USA \\ ${ }^{2}$ Department of Pathology, Chicago Medical School, Rosalind Franklin University of Medicine and Science, North Chicago, \\ $\mathrm{IL}$, USA \\ Correspondence to: Kenneth D. Beaman, email: kenneth.beaman@rosalindfranklin.edu \\ Keywords: tumor microenvironment (TME); breast tumor; CD8 ${ }^{+}$T cells; hematopoietic stem cells (HSC); vacuolar ATPase \\ Received: July 05, $2018 \quad$ Accepted: August 13, $2018 \quad$ Published: September 04, 2018 \\ Copyright: Sahoo et al. This is an open-access article distributed under the terms of the Creative Commons Attribution License 3.0 \\ (CC BY 3.0), which permits unrestricted use, distribution, and reproduction in any medium, provided the original author and source \\ are credited.
}

\section{ABSTRACT}

The interaction of recruited immune effector cells and cancer cells within tumor microenvironment (TME) shapes the fate of cancer progression and metastasis. Many cancers including breast cancer, express a specific vacuolar ATPase (a2V) on their cell surface which acidifies the extracellular milieu helping cancer cell proliferation and metastasis. To understand the role of immune cell-associated-a2V during breast tumor pathogenesis, we knocked-out a2V (KO) from the hematopoietic stem cells (HSC) and generated breast tumors in mice. The a2V-KO mice developed faster growing, larger, and metastatic breast tumors compared to control mice. Further investigation of the TME revealed a significant reduction in the presence of $\mathrm{CD4}^{+}$and $\mathrm{CDB}^{+} \mathrm{T}$ cells in the a2V-KO tumors. Targeted RNA-Seq of the cells of the TME demonstrated that pro-inflammatory cytokines, death receptors, death receptor ligands, and cytotoxic effectors were significantly down-regulated within the a2V-KO TME. Interestingly, analysis of immune cells in the blood, spleen, and thymus of the non-tumor bearing a2V-KO mice revealed a significant decrease in $\mathrm{CD4}^{+}$and $\mathrm{CDB}^{+} \mathrm{T}$ cell populations. For the first time, this study demonstrates that inhibition of V-ATPase expression in HSC leads to a decrease in $\mathrm{CD4}^{+}$and $\mathrm{CD8}^{+} \mathrm{T}$ cell populations and thus promotes breast tumor growth and metastasis.

\section{INTRODUCTION}

The tumor microenvironment (TME) and the interactions between breast cancer cells, immune cells, and their mediators play an important role during tumor progression and metastasis [1]. The TME is infiltrated with various non-immune cells as well as immune cells such as macrophages, dendritic cells, myeloid derived dendritic cells (MDSC), B cells, natural killer (NK) cells and $T$ cells [2-4]. An effective immune response against proliferating tumor cells requires complex interplay among all of the infiltrating immune cells as well as tumor cells. For example, it is well established that both cytokine producing $\mathrm{CD} 4^{+} \mathrm{T}$ helper $\left(\mathrm{T}_{\mathrm{H}}\right)$ cells and $\mathrm{CD} 8^{+}$cytotoxic $\mathrm{T}$ $\left(\mathrm{T}_{\mathrm{C}}\right)$ cells are two key players within the TME. The $\mathrm{CD} 4^{+}$ cells provide necessary factors for priming $\mathrm{CD} 8^{+}$cells and for the expansion of tumor-specific $\mathrm{CD}^{+} \mathrm{T}_{\mathrm{C}}$ cells [5]. $\mathrm{CD} 8^{+} \mathrm{T}_{\mathrm{C}}$ cells cause tumor cell apoptosis through different mechanisms such as the direct binding of the Fas ligand to the Fas receptor on tumor cell surface, recognition of specific epitopes on the tumor cell surface, the release of pore forming perforin, and by secreting cell lysing granzymes. In addition, both $\mathrm{CD} 4^{+} \mathrm{T}_{\mathrm{H}}$ cells and $\mathrm{CD} 8^{+}$ $\mathrm{T}_{C}$ cells induce cell death indirectly by releasing proinflammatory cytokines like IFN- $\gamma$, TNF- $\alpha$ and GM-CSF $[6,7]$. Tumor cells can also dampen the activation and 
proliferation of antigen specific $\mathrm{CD} 4^{+} \mathrm{T}_{\mathrm{H}}$ cells and $\mathrm{CD} 8^{+}$ $\mathrm{T}_{\mathrm{C}}$ cells through binding of programmed death ligand (PDL1) to the PD-1 receptor on T cells. The binding of PD-1 to PD-L1 results in enhanced apoptosis in the antigen specific $\mathrm{CD}^{+} \mathrm{T}_{\mathrm{H}}$ cells and $\mathrm{CD} 8^{+} \mathrm{T}_{\mathrm{C}}$ cells [8]. Tumor induced MDSCs are also known to suppress the activity, induce tolerance of the various $\mathrm{T}$ cells, and cause apoptotic death of $\mathrm{CD} 8^{+} \mathrm{T}_{\mathrm{C}}$ cells [9-11]. Furthermore, rapidly proliferating tumor cells acidify the TME, which in turn increases immune cell death and reduces effectiveness of adoptive immunotherapy [12-14].

The vacuolar-ATPase is a multi-subunit $\mathrm{H}^{+}$-proton pump that is present on the membrane of intracellular vesicles and maintains intracellular $\mathrm{pH}$ in normal cells. A specific isoform of the vacuolar-ATPase, a2V, is also expressed on the surface of cancer cells where it acidifies the extracellular milieu and thus promotes growth, metastasis and chemo-resistance of the cancer cells [15-19]. a2V is encoded by the ATP6VOa2 gene and its expression is tissue specific $[15,20,21]$. For example, a2V is also expressed in cells of hematopoietic origin such as lymphocytes, monocytes and neutrophils [22-24]. Previous in vitro studies have demonstrated that the secreted peptide from cancer-associated a2V, a2V $\mathrm{N}$-terminal domain (a2NTD) modulates IL-1 $\beta$ secretion in THP- 1 cells and peripheral blood mononuclear cells [22, 23]. Furthermore, cancer-associated a2NTD modulates the pro-tumorigenic properties of monocytes, macrophages and neutrophils by changing to an alternatively activated phenotype [25-27].

Host-associated a2V also plays an important role during breast cancer progression. The inhibition of hostassociated a2 $\mathrm{V}$ expression in mammary epithelial cells leads to a reduction in glycosylation of the extracellular matrix (ECM), resulting in soft, highly inflammatory and metastatic breast tumors [28]; however, the precise effect of host immune cell-associated a2V inhibition on breast cancer progression is not known. In this study, we generated a conditionally knocked out $(\mathrm{KO})$ mouse model in which expression of a $2 \mathrm{~V}$ was inhibited from the hematopoietic stem cells (HSCs). Following implantation of a syngeneic tumor cell line in the mammary fat pad of mice, the loss of a2V in the HSCs led to enhanced breast tumor growth and metastasis. Investigation of the TME revealed a significant reduction of $\mathrm{CD} 4^{+}$and $\mathrm{CD}^{+} \mathrm{T}$ cells in the a2V-KO tumors. In addition, targeted RNA-Seq of the TME demonstrated that pro-inflammatory cytokines, death receptors, effector molecules, and pro-apoptotic genes were significantly down regulated, while antiapoptotic genes remained unchanged. The reduction in recruitment of $\mathrm{CD}^{+}$and $\mathrm{CD} 8^{+} \mathrm{T}$ cells in the TME is a reflection of $\mathrm{T}$ cell populations in the periphery, as seen by analysis of immune cells in the spleen and blood of nontumor bearing mice. Further investigation of the decrease of $\mathrm{T}$ cells in periphery revealed a defect in production of $\mathrm{T}$ cells in the bone marrow. Collectively, these results demonstrate, for the first time, that the depletion of HSCassociated $\mathrm{a} 2 \mathrm{~V}$ leads to a reduction of $\mathrm{CD} 4^{+}$and $\mathrm{CD} 8^{+} \mathrm{T}$ cells in the periphery that promotes breast cancer growth and metastasis.

\section{RESULTS}

\section{Lack of HSC-associated a2V leads to an increase in growth and size of breast tumors}

To understand the role of immune cell-associated $\mathrm{a} 2 \mathrm{~V}$ in breast cancer pathogenesis, we generated a conditional KO mouse model (Figure 1A) that lacks a2V in all the cells derived from the HSCs. We detected 5 fold and 12 fold reduction in a2V transcript levels in HSCs and in circulating white blood cells, respectively, in a2 $\mathrm{V}-\mathrm{KO}$ $\left(\mathrm{a} 2 \mathrm{~V}^{\mathrm{f} / \mathrm{fl}} \mathrm{Vav} 1^{\mathrm{CreTg} / 0}\right)$ mice as compared to control $\left(\mathrm{a} 2 \mathrm{~V}^{\mathrm{fl} / \mathrm{fl}}\right)$ mice (Figure 1B). In contrast, the transcript levels of other isoforms of the ' $\mathrm{a}$ ' subunit, namely V0a1, V0a3, and V0a4, did not show a significant change in HSCs (Supplementary Figure 1A) by qRT-PCR. As demonstrated by IFA, a2V was also visibly absent at protein level in the HSCs collected from bone marrow (Figure 1C) and in ex vivo differentiated bone marrow-derived macrophages (Supplementary Figure 1B).

To understand how the deletion of a2V in HSC affects breast cancer progression, we implanted a syngeneic tumor cell line, E0771 into the $4^{\text {th }}$ mammary fat pad of control and a2 $\mathrm{V}-\mathrm{KO}$ mice, both of which share the same C57BL/6 background. Tumor growth analysis showed that tumors in a2 $\mathrm{V}-\mathrm{KO}$ mice grew rapidly at a faster rate as evident by the higher mean slope of growth curve of $81.9 \mathrm{~mm}^{3} /$ Day \pm SEM $8.779 \mathrm{~mm}^{3} /$ Day in $\mathrm{a} 2 \mathrm{~V}$ $\mathrm{KO}$ mice while mean slope of $31.6 \mathrm{~mm}^{3} /$ Day \pm SEM $5.979 \mathrm{~mm}^{3} /$ Day in the control mice (Figure 2A). The isolated tumors from both control and a2V-KO mice appeared solid upon inspection and were phenotypically similar except for size and mass (Figure 2B). The tumors of a $2 \mathrm{~V}-\mathrm{KO}$ mice grew 2.5 times larger in mass compared to the control mice on the $14^{\text {th }}$ day post-implantation (mean $1145 \mathrm{mg} \pm \mathrm{SEM} 86.5 \mathrm{mg}$ vs mean $456.6 \mathrm{mg} \pm \mathrm{SEM}$ $59.6 \mathrm{mg} ; p<0.0001$; Figure 2B). To further investigate the tumors, histopathological evaluation of $\mathrm{H} \& \mathrm{E}$ stained tumor sections was performed. The control tumors showed confluent layers of viable tumor (large cuboid) cells with microscopic foci of necrotic (pink area devoid of nuclei) areas and also micro-hemorrhagic (red) areas. The edges of the necrotic areas were heavily infiltrated with higher number of mononuclear cells and few polymorphonuclear cells (Figure 2C). On the other-hand, the tumors from $\mathrm{a} 2 \mathrm{~V}-\mathrm{KO}$ mice showed large areas of viable tumor foci surrounded by necrotic zones. The necrotic zones were larger in area and were filled with pyknotic cells and cells showing karyolysis. Many tumor sections also displayed zones of hemorrhage (not shown). Furthermore, the a2 $\mathrm{V}-\mathrm{KO}$ tumors also displayed a large infiltration of 
mononuclear cells around the necrotic zones (Figure 2C). The faster growing and larger tumors in a2 $\mathrm{V}-\mathrm{KO}$ mice suggest that the infiltrating immune cells are not efficient in restricting tumor cell proliferation.

\section{a2V deletion in HSCs cause altered recruitment of immune cell populations into the TME}

To understand the TME of a2V-KO tumors, we analyzed the number of infiltrated $\mathrm{CD} 45^{+}$cells by flowcytometry. The majority of the infiltrated $\mathrm{CD} 45^{+}$cells were of myeloid origin $\left(\sim 75 \% \mathrm{CD} 11 \mathrm{~b}^{+}\right.$cells in control mice and $\sim 85 \% \mathrm{CD}^{1} 1 \mathrm{~b}^{+}$cells in a $2 \mathrm{~V}-\mathrm{KO}$ mice, data not

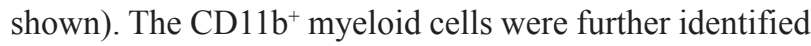
as $\mathrm{CD} 11 \mathrm{~b}^{+} \mathrm{F} 4 / 80^{+}$tumor associated macrophages (TAM), $\mathrm{CD}_{11} \mathrm{~b}^{+} \mathrm{GR} 1^{+} \mathrm{MDSC}, \mathrm{CD} 11 \mathrm{~b}^{+} \mathrm{Ly}_{6 \mathrm{G}^{+}}$tumor associated neutrophils (TAN). There was no significant difference $(p=0.7)$ in the number of TAMs between the TME of control and a2V-KO mice (Supplementary Figure 2A). However, there were twice more MDSC (mean 61,380 \pm SEM 10,598 vs mean 126,606 \pm SEM 20,735; $p=0.022$,
Figure $3 \mathrm{~A}$ ) were present in the a2V-KO TME. Although, the number of TANs displayed a similar trend with mean $66,800 \pm \mathrm{SD} 14,485$ in control TME vs mean $82,250 \pm$ SD 32,375 in a2V-KO TME; $p=0.3810$, there was no significant difference between the groups (Supplementary Figure 2D). In contrast, we found a significant difference in the infiltrated lymphoid cell populations. There was a 3.26 fold increase in recruitment of lymphoid cells in control tumors compared to the a2V-KO tumors. Further analysis demonstrate that there was no significant difference in the $\mathrm{CD}^{+} 9^{+} \mathrm{CD}^{-} \mathrm{B}$ cell populations $(p=0.36$, Supplementary Figure 2B) and CD19-CD3-NKp46 ${ }^{+} \mathrm{NK}$ cell populations ( $p=0.064$, Supplementary Figure $2 \mathrm{C}$ ). On the other hand, the number of $\mathrm{CD}^{+} \mathrm{CD} 19^{-} \mathrm{T}$ cell populations were significantly reduced in a2 $\mathrm{V}-\mathrm{KO} \mathrm{TME}$ (mean 407,749 \pm SEM 173,278 vs mean 75,288 \pm SEM 17,$374 ; p<0.0389$, Figure 3B) compared to the TME of control mice. The reduced number of $\mathrm{CD}^{+} \mathrm{CD} 19^{-}$total $\mathrm{T}$ cells was due to the significantly reduced number of the $\mathrm{CD}^{+}{ }^{+} \mathrm{CD} 19^{-} \gamma \delta \mathrm{TCR}^{-} \alpha \beta$ T cells $(p<0.0001$, Figure $3 \mathrm{C})$. However, this reduction of $\mathrm{CD}^{+} \mathrm{CD} 19^{-}$total $\mathrm{T}$ cells was
A)
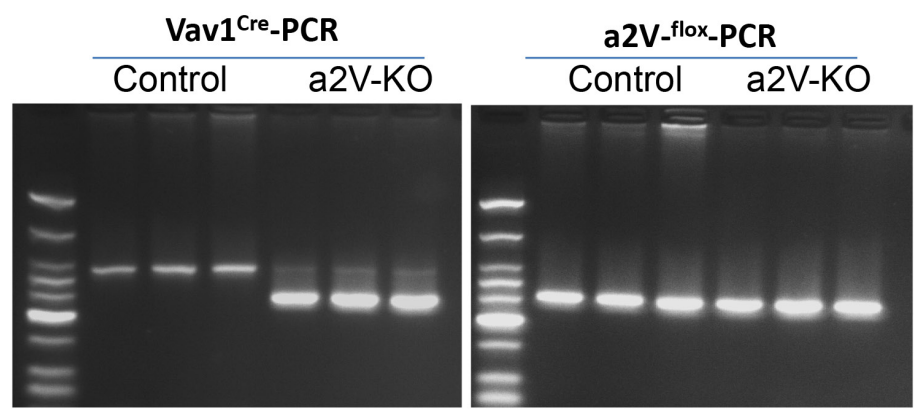

B)

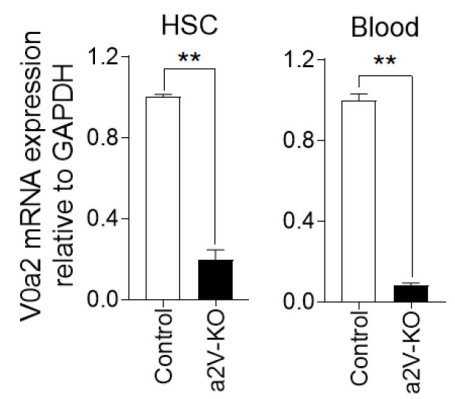

C)
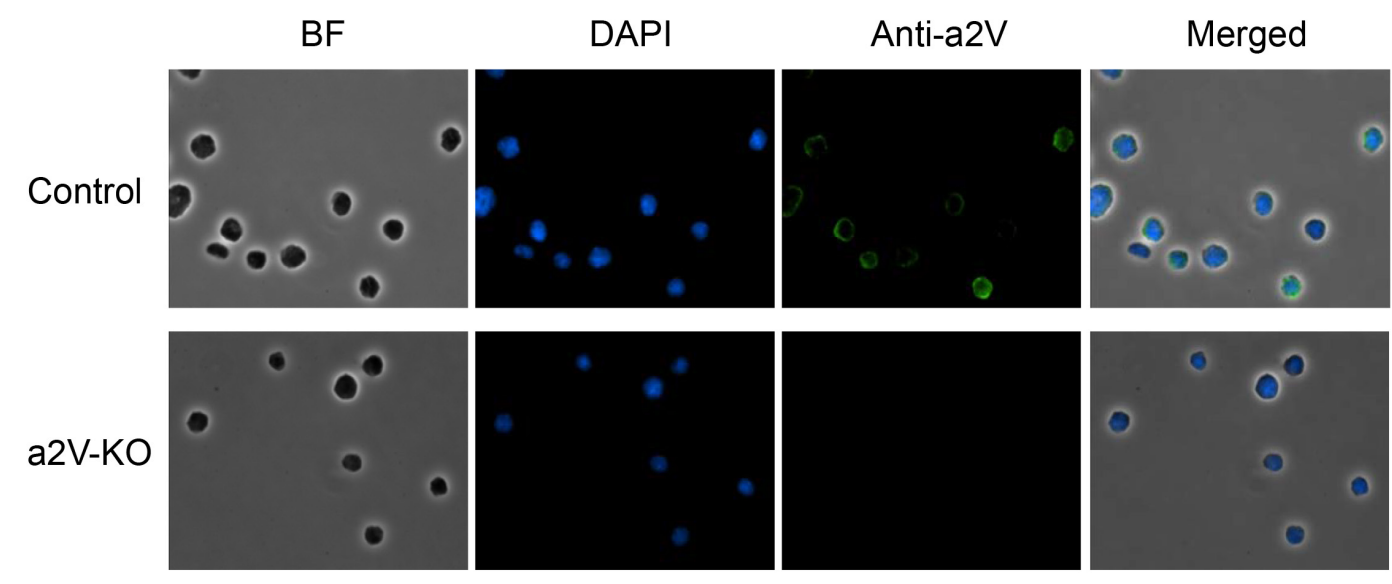

Figure 1: Hematopoietic stem cells lack a2V expression in a2V-KO mice. (A) Representative genomic DNA PCR gel image for Vav1 ${ }^{\text {Cre }}$ transgene (left panel) and LoxP sites (right panel) from control (a2 $\mathrm{V}^{\mathrm{fl} / \mathrm{fl}}$ ) and a2 $\mathrm{V}-\mathrm{KO}$ mice $\left(\mathrm{a} 2 \mathrm{~V}^{\mathrm{fl} / \mathrm{fl}} \mathrm{Vav} 1^{\mathrm{CreT} / 0}\right)(\mathrm{n}=3)$ is shown. (B) Relative mRNA level of V0a2 isoform of V-ATPase in HSCs isolated from bone marrow and in white blood cells of mice is shown. Mouse GAPDH is used as an endogenous control for normalization. Data is represented as mean \pm SEM ( $\mathrm{n}=6$, Mann-Whitney $U$ test, ${ }^{* *} p<0.01$ ). (C) Representative IFA image showing lack of a2 $\mathrm{V}$ protein (green fluorescence) in HSCs isolated from bone marrow of a2 V-KO mice ( $n=6,40 X$ magnification). 
not due to difference in $\mathrm{CD}^{+} \mathrm{CD}^{-}{ }^{-} \gamma \delta \mathrm{TCR}^{+} \gamma \delta \mathrm{T}$ cell population ( $p=0.1698$, Figure $3 \mathrm{C}$ ). Further analysis of the $\alpha \beta$ T cells revealed significant reduction in both $\mathrm{CD}^{+} \mathrm{T}_{\mathrm{H}}$ $(p<0.0001)$ and $\mathrm{CD}^{+} \mathrm{T}_{\mathrm{C}}$ cell $(p<0.0002)$ populations in the TME of a2 $\mathrm{V}-\mathrm{KO}$ mice. The mean number per gram of CD4 ${ }^{+} \mathrm{T}_{\mathrm{H}}$ and $\mathrm{CD}^{+} \mathrm{T}_{\mathrm{C}}$ cells was found to be $841,486 \pm$ SEM 127,272 and 202,010 \pm SEM 77,719\%, respectively, in control mice. In contrast, mean number per gram of $\mathrm{CD}^{+} \mathrm{T}_{\mathrm{H}}$ and $\mathrm{CD} 8^{+} \mathrm{T}_{\mathrm{C}}$ cells in a2 $\mathrm{V}-\mathrm{KO}$ mice were 49,503 \pm SEM 10,041 and 5,579 \pm SEM 2,532, respectively (Figure 3D). These results suggest that the higher occurrence of MDSC along with reduced number $\mathrm{CD}^{+} \mathrm{T}_{\mathrm{C}}$ cells and the cytokine producing $\mathrm{CD}^{+} \mathrm{T}_{\mathrm{H}}$ cells within the TME of a2 $\mathrm{V}-\mathrm{KO}$ mice can be responsible for the larger and faster growing tumor in those mice.

\section{Tumors of a2V-KO mice develop a pro- tumorigenic environment}

To better understand the cytokines and chemokines that contribute to the dynamics of the TME, we performed targeted RNA-Seq via Next Generation Sequencing (NGS). Here we analyzed 485 genes out of which 3 genes were significantly upregulated while 144 genes were significantly downregulated (Supplementary Figure 3A). This analysis uncovered that the transcripts of pro-inflammatory cytokines for IL-1 $\alpha$ (3.03 fold, $p=0.0022)$, IL-1 $\beta$ (2.34 fold, $p=0.0043)$, TNF- $\alpha$ (2.1 fold, $p=0.0022)$, IFN- $\gamma$ (21.3 fold, $p=0.0022)$, GMCSF (2.67 fold, $p=0.0152$ ) were significantly decreased in the a2V-KO TME (Figure 4A). The results indicate
A)

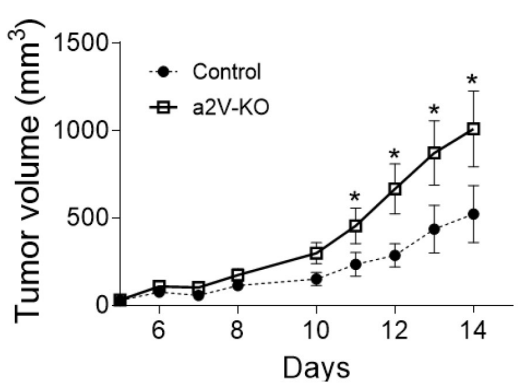

C)

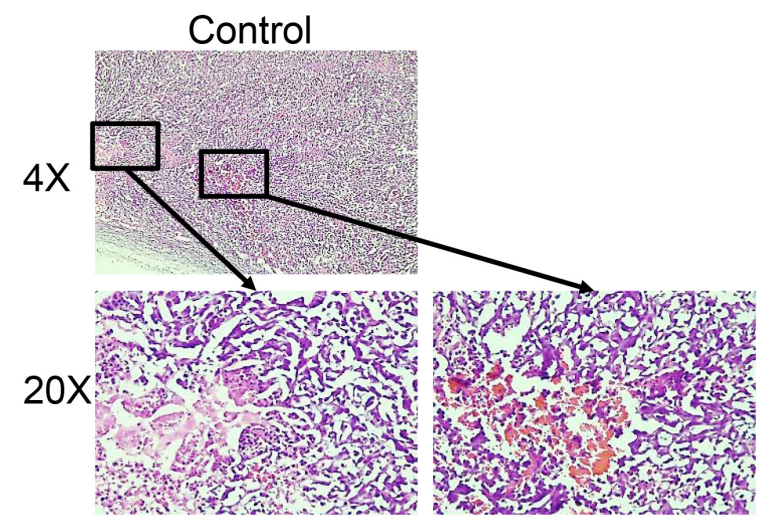

B)
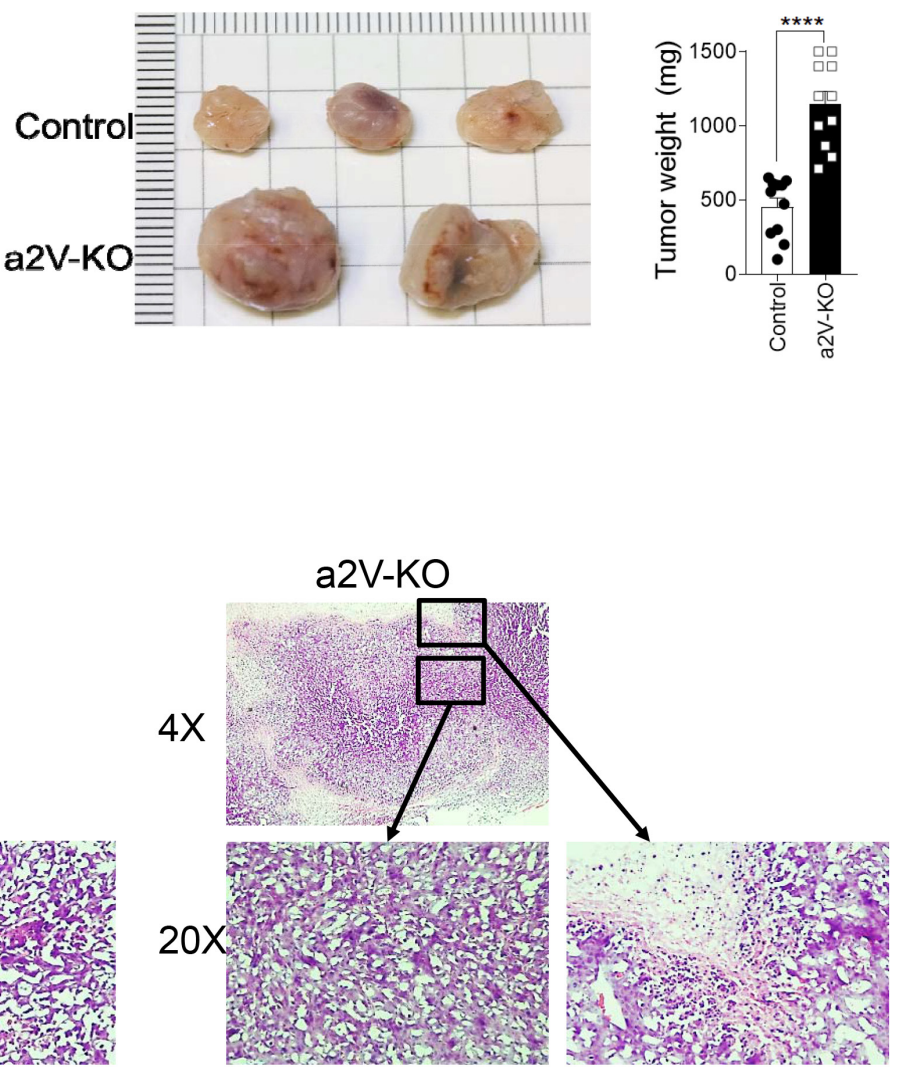

Figure 2: Lack of immune cell-associated a2V leads to an increase in growth and size of breast tumors. (A) Tumor growth curve: $5 \times 10^{5}$ E0771 cells were resuspended in $50 \mu \mathrm{HBSS}$ and $50 \mu \mathrm{l}$ Matrigel and were injected into the $4^{\text {th }}$ mammary fat pad of 8 week old female littermate control and a2V-KO mice. Tumor length and width were measured with a digital caliper and tumor volume was determined by the following formula: volume $=\mathrm{LxWxWx} 0.5$. Results are shown as mean $\pm \mathrm{SEM}$ (pooled results from three independent experiments with total $\mathrm{n}=11$, Mann-Whitney $U$ test, ${ }^{*} p<0.05$ ). (B) Left panel shows a representative picture of breast tumors from control and a2 V-KO mice collected on day 14 post-implantation. Right panel is graphical representation of pooled tumor weight from 3 independent experiments harvested 14 days post-implantation ( $\mathrm{n}=11$, mean \pm SEM, Mann-Whitney $U$ test, $\left.{ }^{* * * *} p<0.0001\right)$. (C) Representative images of hematoxylin and eosin stained breast tumor sections collected on day 14 post-implantation from control (left panels) and a2 V-KO (right panels) mouse. The images in upper panels show overall histopathology at $4 \mathrm{X}$ magnification. The images in lower panels are the 20X magnified images from the indicated area. The control tumor sections (left panels) show areas of micro-necrotic and hemorrhagic areas surrounded by tumor and infiltrating cells. In the a2 $\mathrm{V}-\mathrm{KO}$ tumors (right panels), the tumor cell zones are surrounded by large necrotic pink areas with pyknotic and karyolytic cells. 
that the TME of control mice is pro-inflammatory and creates an anti-tumorigenic niche. In contrast, the TME of a2 $\mathrm{V}-\mathrm{KO}$ mice is not as pro-inflammatory in nature, and thus creates a pro-tumorigenic environment which is conducive for tumor growth (Figure 4A). The proinflammatory cytokines like TNF- $\alpha$, IFN- $\gamma$ and GM-CSF are known to induce cell death indirectly by increasing expression of death receptors and death ligands on cells $[6,7]$. Our results demonstrate that the transcript levels of pro-apoptotic death receptor, Fas (1.95 fold, $p=0.0087$ ), death receptor ligands like Fas ligand (FasL; 14.2 fold, $p=0.0022$ ) and TNF-related apoptosis-inducing

A)
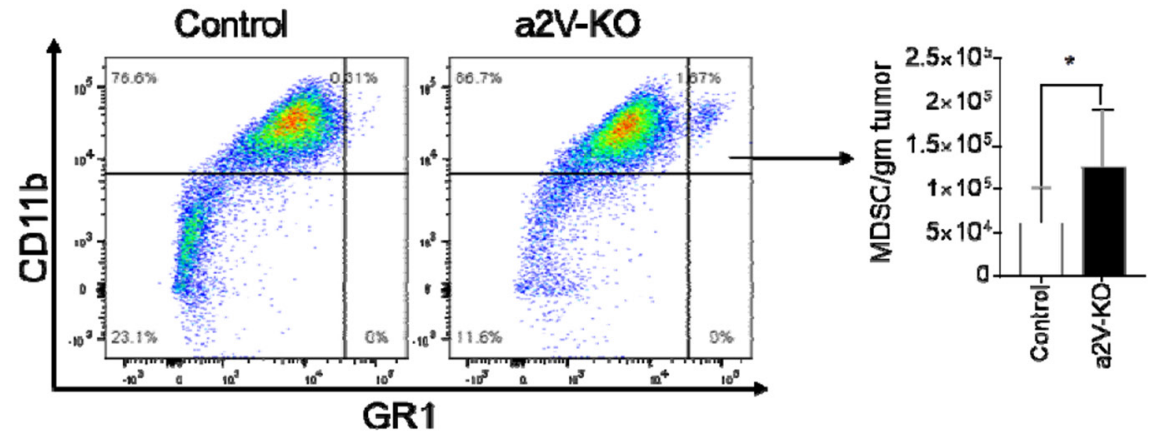

B)
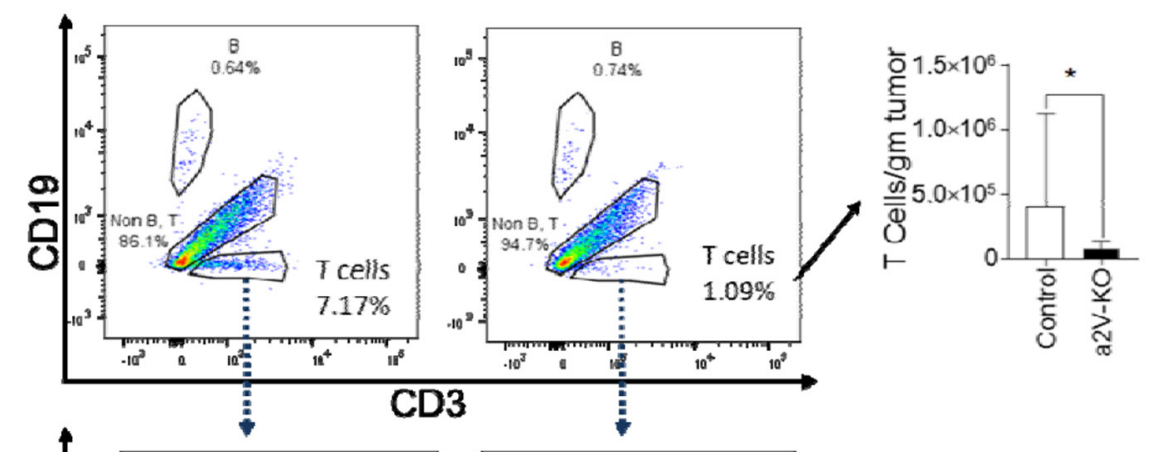

C)
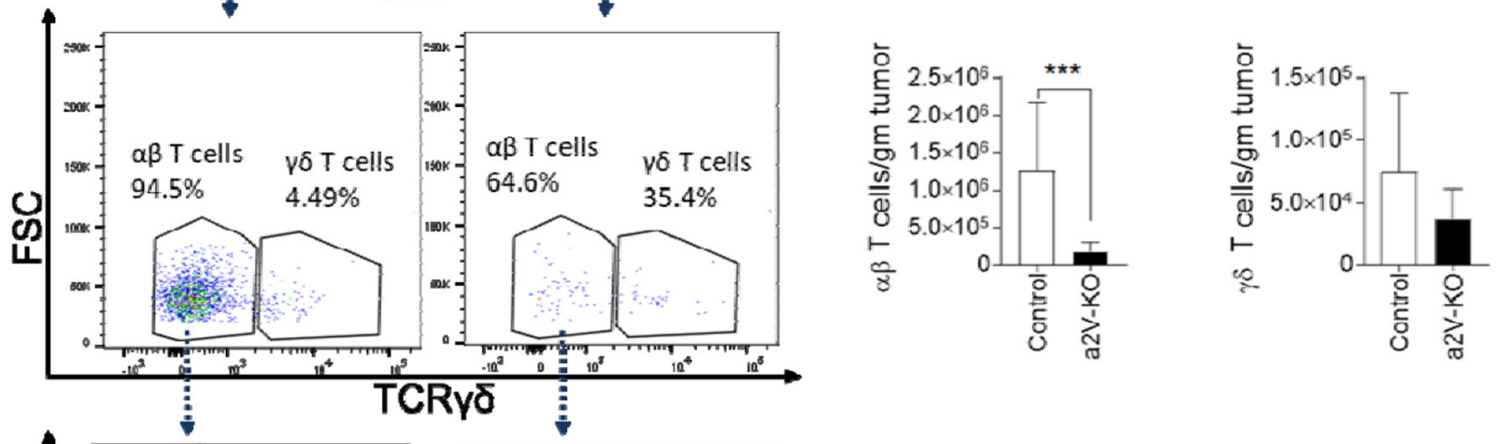

D)
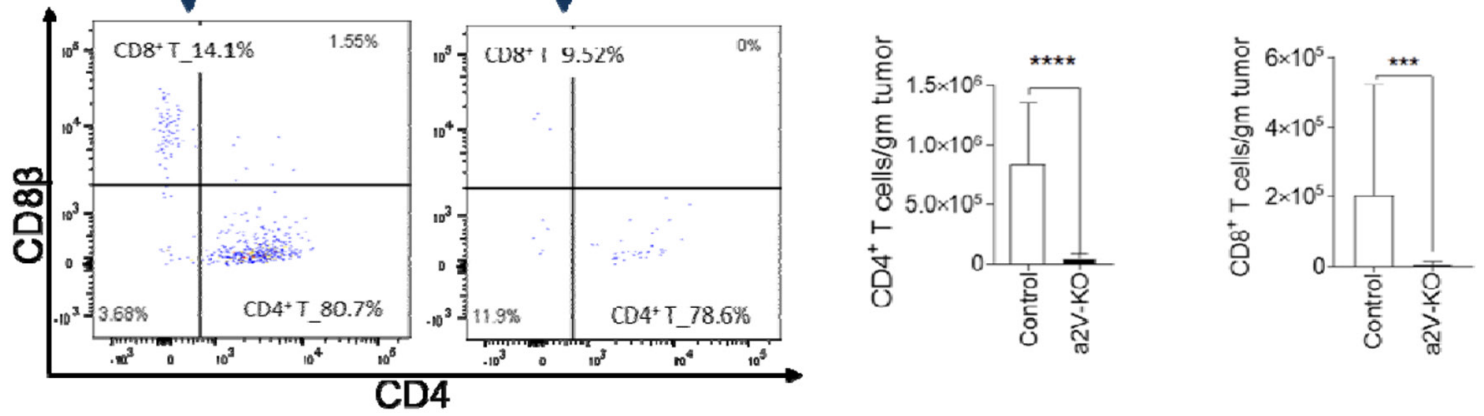

Figure 3: a2V deletion in HSCs cause altered recruitment of immune cell populations into the TME. After 14 days of implantation, tumors from control and a2 V-KO mice were harvested, mechanically disrupted, and digested with Collagenase IV and DNAse I to obtain a single cell suspension. The single cells were enriched for CD45 expression by MACS and subjected to flow-cytometry and counted manually with trypan blue. Representative histograms are shown in the left side. Bar graphs show the number of single, live, CD $45^{+}$cells per gram of tumor in the TME. (A) MDSC (B) T cells (C) $\alpha \beta$ T cells and $\gamma \delta$ T cells (D) CD4 $4^{+} \mathrm{T}_{\mathrm{H}}$ cells and CD8 ${ }^{+} \mathrm{T}_{\mathrm{C}}$ cells. Pooled results from three independent experiments with control $\mathrm{n}=14$ and a2V-KO $\mathrm{n}=11$, mean $\pm \mathrm{SEM}$, Mann-Whitney $U$ test, ${ }^{*} p<0.05,{ }^{* *} p<0.01$, ${ }^{* * *} p<0.001$, and ${ }^{* * * *} p<0.0001$. 
ligand (TRAIL; 2.3 fold, $p=0.0022$ ) are significantly decreased in the $\mathrm{a} 2 \mathrm{~V}-\mathrm{KO}$ tumors (Figure $4 \mathrm{~B}$ ). This data suggests that, the tumor cells of a2 $\mathrm{V}-\mathrm{KO}$ mice are not undergoing apoptosis, and therefore lead to a larger tumor. Furthermore, we also found that there is no difference in the anti-apoptotic transcript levels of $\mathrm{Bcl} 2(p=0.1385)$, $\operatorname{Bcl} 21(p=0.1320)$, and Myc $(p=0.0931)$. This result also implies that the larger size of the a2V-KO tumors is not due to any protective effect of anti-apoptotic genes; rather it is due to a lack of pro-apoptotic factors in the TME (Figure 4C). This data is also supported by our findings that there is less recruitment of CD8 ${ }^{+} \mathrm{T}_{\mathrm{C}}$ cells (Figure 3D and Supplementary Figure 3B) in to the TME of a2V$\mathrm{KO}$ mice. When compared to the control TME, there is a significant decrease in transcript numbers of cytotoxic effector molecules like perforin ( 2.89 fold, $p=0.0087$ ), granzyme-a (4.38 fold, $p=0.0022)$, and granzyme-b (3.87 fold, $p=0.0022$ ) in the TME of a2 V-KO mice (Figure 4D). The 3 genes whose transcript levels were significantly increased in the a2V-KO TME are: Ackr2 (Atypical chemokine receptor 2, D6; 2.1 fold higher, $p=0.026$ ), Ppbp (Pro-platelet basic protein, CXCL 7; 3.0 fold higher, $p=0.0087$ ), and $\mathrm{Mmp} 3$ (Matrix metalloproteinase-3; 2.5 fold higher, $p=0.0152$ ) (Figure 4E). D6 is a chemokine decoy receptor which sequester pro-inflammatory chemokines [29] while both CXCL7 and MMP3 can degrade the extracellular matrix and promote tumor growth and metastasis $[30,31]$. Taken together, the lack of cytotoxic cells, cytotoxic effector molecules, and proapoptotic molecules within a pro-tumorigenic environment contributed to the large tumor in the $\mathrm{a} 2 \mathrm{~V}-\mathrm{KO}$ mice.

A)
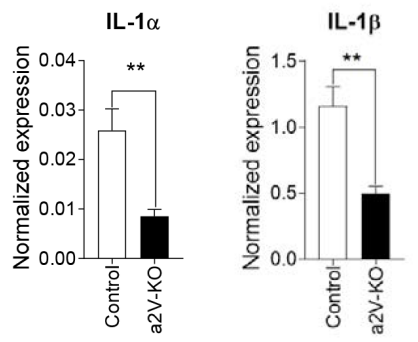

\section{Pro-inflammatory cytokines}

B)

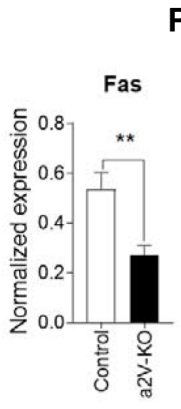

Pro-apoptotic genes
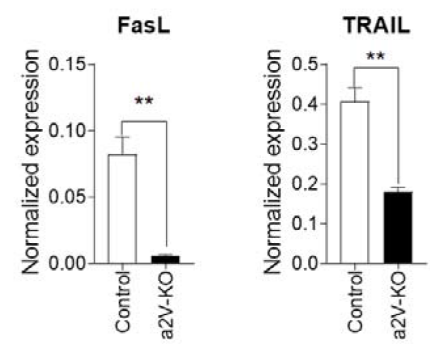

D)

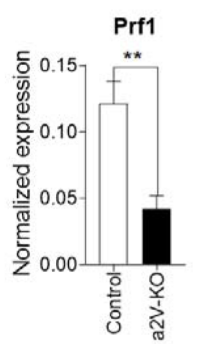

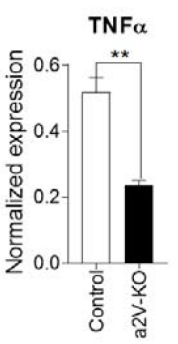
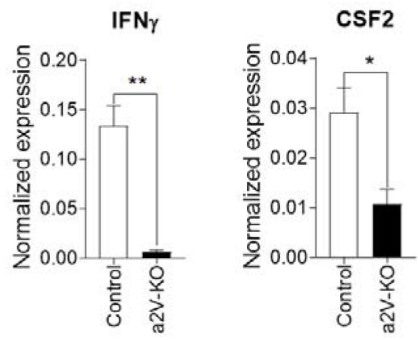

C)

Anti-apoptosis associated genes
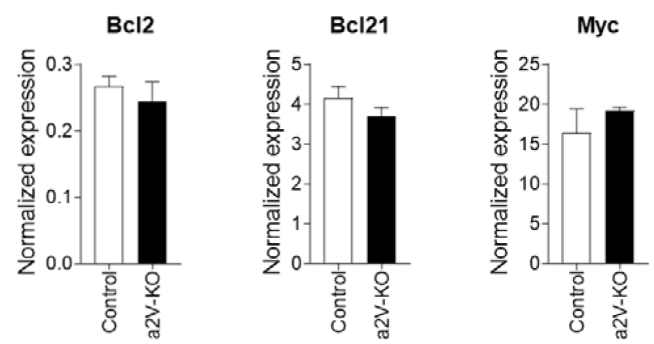

E)

Upregulated genes in a2V-KO TME

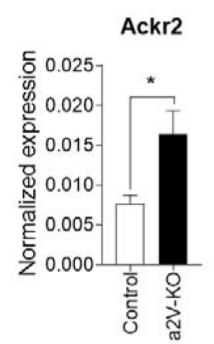

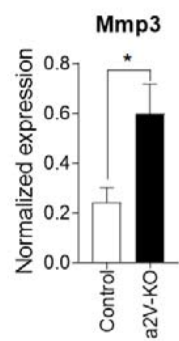

Figure 4: Tumors of a2 V-KO mice develop a pro-tumorigenic environment. Equal amounts of tumor RNA was used for targeted RNA-Seq (Miseq) and data were analyzed online using Qiagen's data analysis center. Eight housekeeping genes were used to normalize gene expression. Bar graphs show transcript levels of (A) Pro-inflammatory cytokines (B) Pro-apoptotic genes (C) Anti-apoptosis associated genes (D) Cytotoxic effector molecules (E) the 3 upregulated genes in a2V-KO TME. Pooled results from two independent experiments with $\mathrm{n}=6$, mean $\pm \mathrm{SEM}$, Mann-Whitney $U$ test, ${ }^{*} p<0.05$, and ${ }^{* *} p<0.01$ ). 


\section{Lungs of a2 V-KO mice show increased metastasis}

To understand if the loss of a2 $\mathrm{V}$ in the hematopoietic cells impacts the ability of tumor cells to metastasize, we searched for metastatic cancer cells forming a distinct focus in the lungs of a2 $\mathrm{V}-\mathrm{KO}$ and control mice. Time point analysis of cancer metastasis show that the lungs from non-tumor bearing control or a2 $\mathrm{V}-\mathrm{KO}$ mice did not have any metastasis (Figure 5A). However, on day 14 of posttumor-implantation, breast tumor cells metastasized to the lungs of a2 $\mathrm{V}-\mathrm{KO}$ mice but not into the lungs of control mice. The implanted E0771 tumor cells form significantly higher ( $p=0.006)$ numbers of metastatic foci of cancer cells that are visibly different from the surrounding lung epithelial cells (Figure 5B and 5C). These results showed that the breast tumors of a2 $\mathrm{V}-\mathrm{KO}$ mice metastasize rapidly compared to control mice, suggesting a less restrictive TME that permits breast cancer cells to metastasize easily.

\section{Deletion of a2 $\mathrm{V}$ in hematopoietic cells results in reduced population of $\alpha \beta$ T cells}

HSCs are the progenitors of most immune cell populations. To understand if the change in immune cell populations in TME is due any intrinsic defect in immune
A)

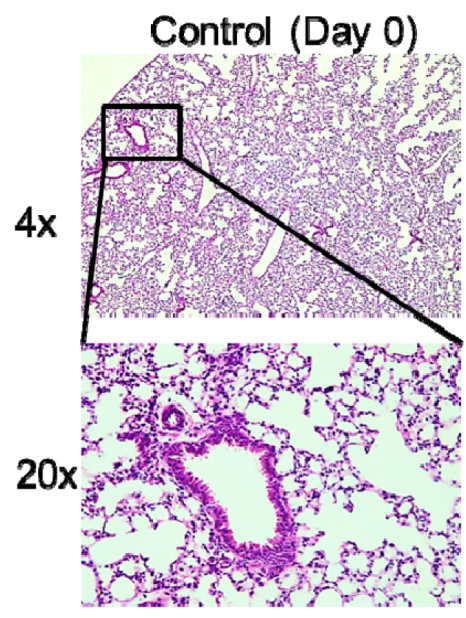

B)

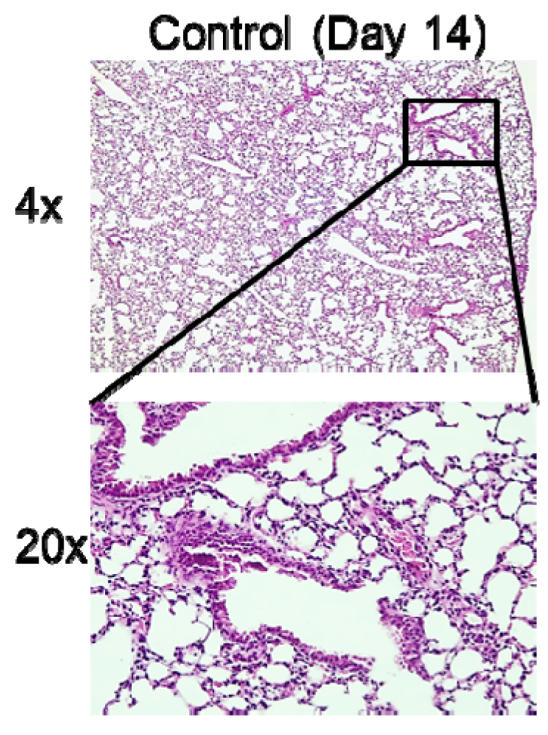

a2V-KO (Day 0)

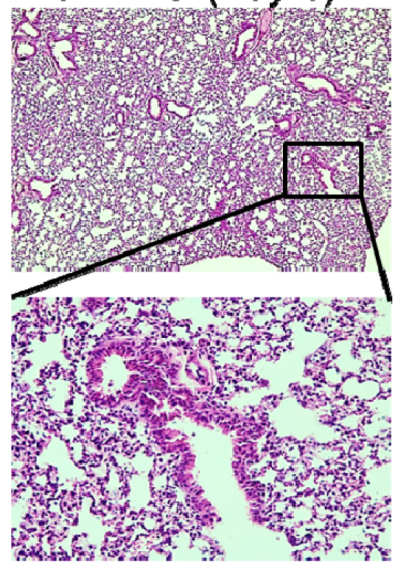

C)

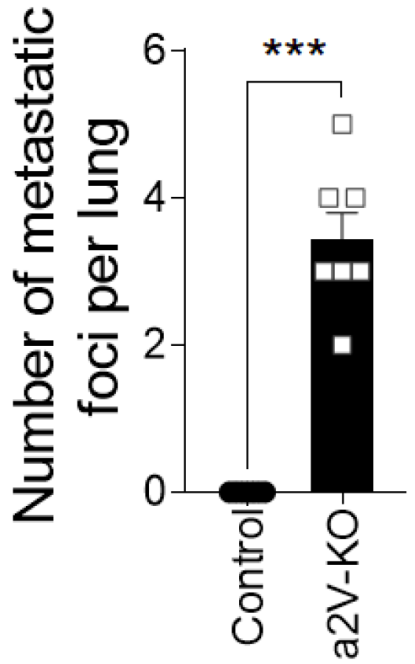

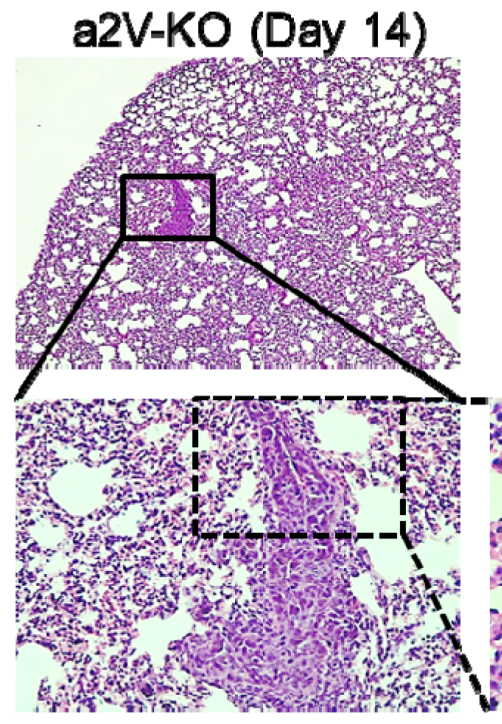

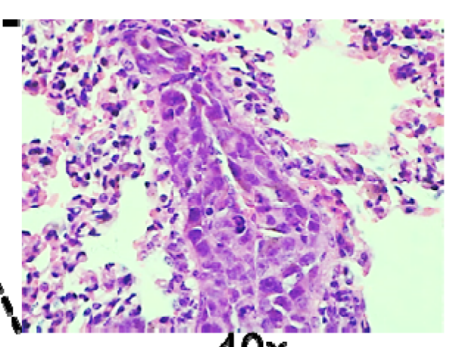

Figure 5: Lungs of a2 V-KO mice show increased metastasis. Representative histopathology images of hematoxylin and eosin stained mouse lung sections collected on day 0 (A) or day14 (B) post-implantation from control (left panels) and a2V-KO mice (right panels). The upper panels are at $4 \mathrm{X}$ magnification, while the lower panels are the $20 \mathrm{X}$ magnified images from the indicated solid lined area or 40X (dotted line from 20X image). (C) Quantification of metastatic foci per H\&E stained lung sections as observed at 20X magnification on day 14 post-implantation. Day-14 post-implantation lungs are from two independent experiments with $\mathrm{n}=7$, mean \pm SEM, MannWhitney $U$ test, ${ }^{* * *} p<0.001$, while day 0 control lungs are from $\mathrm{n}=5$ mice. 
cell development, we analyzed the splenic and circulating immune cell populations of non-tumor bearing mice by flow-cytometry. The macrophages and MDSC cells are present in a very low percentage in both spleen and blood (data not shown). As expected, the lymphoid cells constituted the majority cell population within the spleen and blood. The population of lymphoid cells in the a $2 \mathrm{~V}$ KO spleen was severely diminished. The percentage of total T cells was reduced 4.8 fold and 16.6 fold in spleen and blood of the a2 V-KO mice, respectively (Figures 6A and $6 \mathrm{~B}$, upper rows). As observed within the TME, only the $\alpha \beta$ T cells, not the $\gamma \delta$ T cells were diminished in the spleen and blood of a2 $\mathrm{V}-\mathrm{KO}$ mice (Figures 6A and 6B, middle rows). In the spleen, the $\alpha \beta \mathrm{T}$ cell percentage was reduced 6.23 fold of a2 $\mathrm{V}-\mathrm{KO}$ mice (mean $22.57 \% \pm \mathrm{SD}$ $0.31 \%$ in control mice vs mean $3.62 \% \pm \mathrm{SD} 0.12 \%$ in a2 $\mathrm{V}$-KO mice) while the $\alpha \beta \mathrm{T}$ cell number was reduced 21 fold (mean $16 \times 10^{6} \pm$ SD $2.6 \times 10^{6}$ in control mice vs mean $0.76 \times 10^{6} \pm \mathrm{SD} 0.13 \times 10^{6}$ in a2V-KO mice). Similar reduction of $\alpha \beta \mathrm{T}$ cell percentage was observed in blood of a2V-KO mice (29.23 fold, mean $25.6 \% \pm$ SD $0.14 \%$ in control mice vs mean $0.88 \% \pm \mathrm{SD} 0.27 \%$ in a2V-KO mice). Further analysis of the $\alpha \beta \mathrm{T}$ cells revealed that the percentage of both $\mathrm{CD}^{+} \mathrm{T}_{\mathrm{H}}$ and $\mathrm{CD}^{+} \mathrm{T}_{\mathrm{C}}$ cells were reduced 25.71 fold and 13.73 fold in spleen, 58.3 fold and 11.16 fold in blood, respectively (Figure 6A and 6B, bottom rows). The percentage of splenic $\mathrm{CD}^{+} \mathrm{T}_{\mathrm{H}}$ cells was determined to be (mean \pm SD) $12.94 \% \pm 0.35 \%$ in control mice, while the percentage (mean $\pm \mathrm{SD}$ ) in a $2 \mathrm{~V}$ $\mathrm{KO}$ mice was found to be $0.50 \% \pm 0.02 \%$. The number of splenic $\mathrm{CD}^{+} \mathrm{T}_{\mathrm{H}}$ cells was determined to be (mean $\pm \mathrm{SD}$ ) $9.2 \times 10^{6} \pm 1.7 \times 10^{6}$ in control mice, while the number of splenic $\mathrm{CD}^{+} \mathrm{T}_{\mathrm{H}}$ cells (mean $\pm \mathrm{SD}$ ) in a2 $\mathrm{V}$-KO mice was determined to be $1.06 \times 10^{5} \pm 0.2 \times 10^{5}$. The percentage of blood CD4 ${ }^{+} \mathrm{T}_{\mathrm{H}}$ cells was found to be (mean $\pm \mathrm{SD}$ ) $11.71 \%$ $\pm 0.32 \%$ in control mice, while the percentage (mean \pm $\mathrm{SD}$ ) in a2V-KO mice was found to be $0.20 \% \pm 0.07 \%$. The mean $\pm \mathrm{SD}$ percentage of splenic $\mathrm{CD}^{+} \mathrm{T}_{\mathrm{C}}$ cells was found to be $7.24 \% \pm 0.21 \%$ in control mice, compared to $0.53 \% \pm 0.77 \%$ in $\mathrm{a} 2 \mathrm{~V}-\mathrm{KO}$ mice, and the mean number $\pm \mathrm{SD}$ of splenic $\mathrm{CD}^{+} \mathrm{T}_{\mathrm{C}}$ cells was found to be $5.1 \times 10^{6} \pm$ $0.8 \times 10^{6}$ in control mice, compared to $1.1 \times 10^{5} \pm 0.35 \times 10^{5}$ in a2 $\mathrm{V}-\mathrm{KO}$ mice, while the mean $\pm \mathrm{SD}$ percentage of $\mathrm{CD} 8^{+}$ $\mathrm{T}_{\mathrm{C}}$ cells in blood was measured to be $8.53 \% \pm 0.0 .08 \%$ in control mice, compared to $0.76 \% \pm 0.18 \%$ in $\mathrm{a} 2 \mathrm{~V}$ $\mathrm{KO}$ mice. Similar reduction is observed in thymus and bone marrow (Figure 6C and 6D). The reason for such reduction is currently unknown. We are currently working to understand the reasons behind such reduction of the $\alpha \beta$ $\mathrm{T}$ cells, but it is beyond the scope of this manuscript.

\section{Depletion of $\mathrm{CD8}^{+}$cytotoxic $\mathrm{T}$ cells in periphery leads to increased tumor growth}

We demonstrated that the diminished occurrence of $\mathrm{CD}^{+} \mathrm{T}_{\mathrm{H}}$ cells and $\mathrm{CD}^{+} \mathrm{T}_{\mathrm{C}}$ cells in the a2 $\mathrm{V}-\mathrm{KO}$ tumor
(Figure 3D) as well as in the periphery (Figures 6A and $6 \mathrm{~B}$, bottom rows) creates a pro-tumorigenic environment that is conducive for tumor growth and metastasis. To understand the relative contribution of $\mathrm{CD}^{+} \mathrm{T}_{\mathrm{H}}$ cells and $\mathrm{CD}^{+} \mathrm{T}_{\mathrm{C}}$ cells in controlling tumor growth and metastasis, we depleted either $\mathrm{CD}^{+} \mathrm{T}_{\mathrm{H}}$ cells or $\mathrm{CD} 8^{+} \mathrm{T}_{\mathrm{C}}$ cells from the control mice. The specific depletion was achieved by administration of specific monoclonal antibodies against CD4 or CD8 antigens or with an isotype matched antibody that was used as a control, before tumor implantation. The depleted status was maintained by recurring administration of the above mentioned antibodies as shown in the schematic (Figures 7A and Supplementary Figure 4). We observed that depletion of $\mathrm{CD}^{+} \mathrm{T}_{\mathrm{C}}$ cells resulted in the most rapidly growing tumors with a mean slope of 59.89 $\mathrm{mm}^{3} /$ Day $\pm 5.079 \mathrm{~mm}^{3} /$ Day $\left(\mathrm{R}^{2}=0.9456\right)$, while depletion of $\mathrm{CD}^{+} \mathrm{T}_{\mathrm{H}}$ cells yielded moderate results with a mean slope of $25.22 \mathrm{~mm}^{3} /$ Day $\pm 2.319 \mathrm{~mm}^{3} /$ Day $\left(\mathrm{R}^{2}=0.9367\right)$; Control mouse tumor growth was the slowest with a mean slope of $12.5 \mathrm{~mm}^{3} /$ Day $\pm 1.321 \mathrm{~mm}^{3} /$ Day $\left(\mathrm{R}^{2}=0.918\right.$; Figure 7B). In addition, depletion of $\mathrm{CD}^{+} \mathrm{T}_{\mathrm{C}}$ cells resulted in the largest tumors (mean $1095 \mathrm{mg} \pm \mathrm{SD} 365 \mathrm{mg}$ ) and grew 3.94 times bigger when compared to the tumors of control mice. In contrast, depletion of $\mathrm{CD}^{+}$cells resulted in tumors of mean $552 \mathrm{mg} \pm \mathrm{SD} 560.4 \mathrm{mg}$ and were 1.99 times bigger compared to the control mice (Figure 7C). To appreciate the effect of depletion on metastasis, the lungs were collected and histological analysis was performed as described earlier. Lungs of mice with depleted $\mathrm{CD}^{+} \mathrm{T}_{\mathrm{C}}$ cells, show metastatic foci while lungs of control mice or mice depleted of $\mathrm{CD}^{+} \mathrm{T}_{\mathrm{H}}$ cells did not show any distinct foci of metastasis (Figure 7D). These findings show that lack of $\mathrm{CD}^{+} \mathrm{T}_{\mathrm{C}}$ cells in the periphery result in faster growing, larger tumors that metastasize to lungs.

\section{DISCUSSION}

V-ATPase is expressed on the surface of breast cancer cells and promotes cancer cell growth, invasion and metastasis [19, 32, 33]. Few studies have looked into the role of cancer-associated V-ATPAse during breast cancer progression and all of them agree that deletion of V-ATPase in cancer cells results in a delay in cancer proliferation and invasion [19, 32, 33]. However the effect of immune cell-associated a2 $\mathrm{V}$ on cancer cell proliferation and metastasis is not known. Deciphering the role of immune cell-associated V-ATPase during breast cancer progression could provide us with a better understanding of other mechanisms that contribute to cancer pathogenesis and metastasis. The present study examines the role of host immune cell-associated V-ATPase during breast tumor pathogenesis by using a mouse model that lacks a2V in the HSCs. Here for the first time we demonstrate that the deletion of a $2 \mathrm{~V}$ in the HSC leads to a significant reduction of $\mathrm{CD}^{+}$and $\mathrm{CD}^{+} \mathrm{T}$ cells in the periphery, which in turn, promotes breast cancer growth and metastasis. 
Majority of the immune cell populations originate from HSCs, while a few cell types are originated in fetal liver [34]. To understand the role of host immune cell-associated a2V on breast tumor pathogenesis, we developed a2 $\mathrm{V}-\mathrm{KO}$ mice model that lacks $\mathrm{a} 2 \mathrm{~V}$ in
HSCs and used E0771 to generate tumors as the E0771 tumors mimic the human disease and metastasize [35]. Deletion of HSC-associated a2V has significant effect on tumor growth and metastasis (Figure 2A and 2B). Although, tumors from both control and a2 $\mathrm{V}-\mathrm{KO}$ mice
SPLEEN
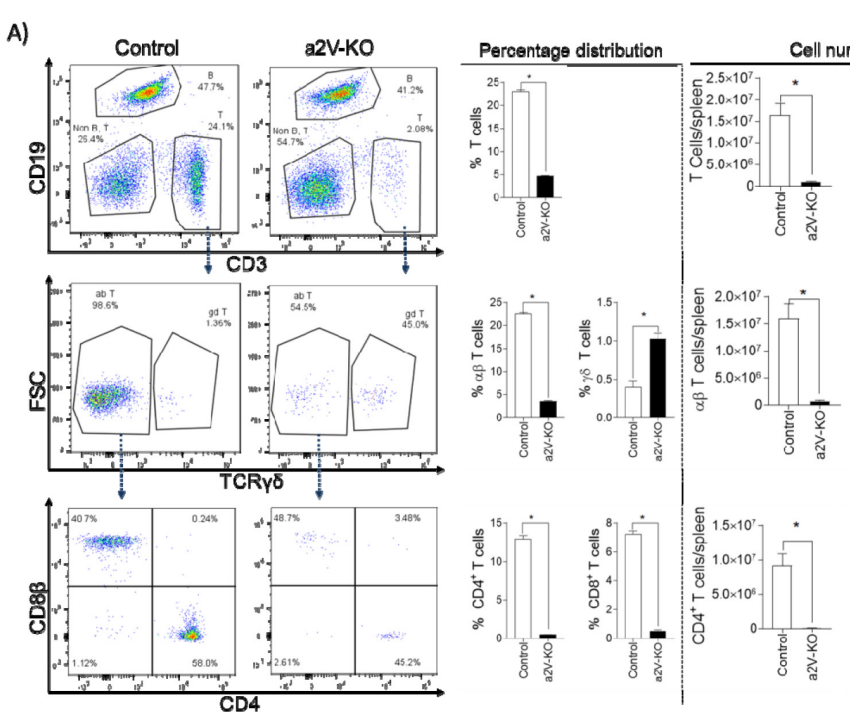

THYMUS
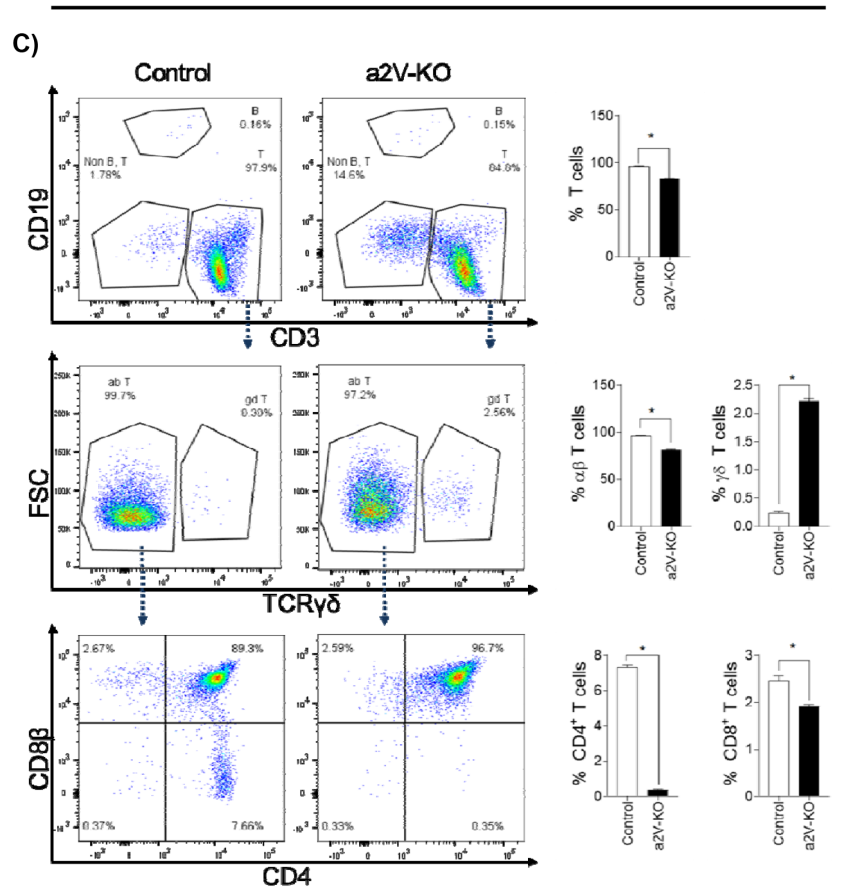
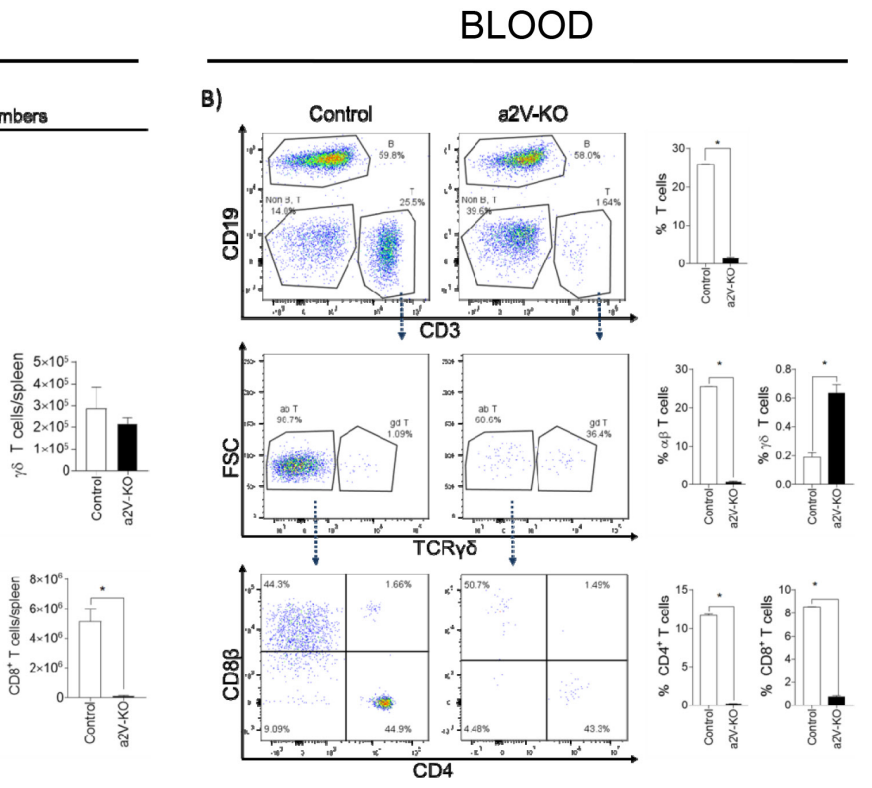

BONE MARROW

D)
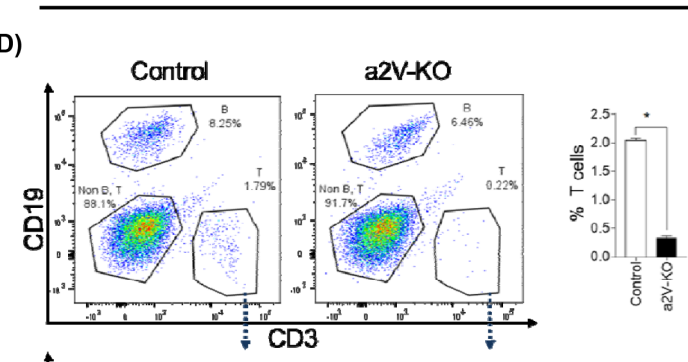

Figure 6: Deletion of $\mathbf{a} 2 \mathrm{~V}$ in hematopoietic cells results in reduced population of $\boldsymbol{\alpha} \boldsymbol{\beta} \mathrm{T}$ cells. Spleen, thymus and flushed bone marrow were collected from control and a2 $\mathrm{V}-\mathrm{KO}$ non-tumor bearing mice and mechanically disrupted to obtain a single cell suspension. Blood was collected with EDTA to prevent clotting. After lysing red blood cells, the cells were subjected to flow-cytometry after live-dead staining. Representative histogram panels for all the samples are shown in the left. Bar graphs show the percentage (A; left panels) and number (A; right panels) of live single cells in the spleen. Furthermore, panels (B, C, and $\mathbf{D})$ show the percentage of live single cells in blood, thymus, and bone marrow, respectively. The upper rows represent T cells, middle rows for $\alpha \beta \mathrm{T}$ cells and $\gamma \delta \mathrm{T}$ cells, and bottom rows represent $\mathrm{CD} 4+\mathrm{T}_{\mathrm{H}}$ cells and CD8 $+\mathrm{T}_{\mathrm{C}}$ cells. Representative experiment with $\mathrm{n}=4$, mean $\pm \mathrm{SD}$, Mann-Whitney $U$ test, ${ }^{*} p<0.05$. 
are phenotypically similar except for size and mass, histologically there are major differences between them. The tumors from control mice have multiple micronecrotic centers and micro-hemorrhagic areas surrounded by infiltrating leukocytes. Similar findings also have been observed in E0771 tumors generated in other mouse models [35] and in human medullary breast cancer [36]. The necrotic zones are of larger size and form a ring shape around the cancer cells in the a2 $\mathrm{V}-\mathrm{KO}$ mice. It is plausible that as the tumor grows larger in mass; the cancer cells migrate outwards, thus creating a necrotic center. Although both control and a2V-KO mice show infiltration of immune cells in the TME, the infiltrating cells of the control mice must be very important in restricting tumor cell proliferation, thus leading to a smaller size tumor. In contrast, the infiltrating cells of the a2 V-KO mice may not be very efficient in controlling tumor cell proliferation, resulting in a larger and faster growing tumor.

The complex interaction between the $\mathrm{CD}^{+} \mathrm{T}_{\mathrm{H}}$ cells and $\mathrm{CD}^{+} \mathrm{T}_{\mathrm{C}}$ cells and other cell types in the TME impacts the outcome of cancer progression and metastasis. We have found that the presence of fewer CD4 ${ }^{+} \mathrm{T}_{\mathrm{H}}$ cells and $\mathrm{CD} 8 \mathrm{~T}_{\mathrm{C}}$ cells in the TME correlates with larger tumor sizes in $\mathrm{a} 2 \mathrm{~V}-\mathrm{KO}$ mice (Figure 3D). Our findings are supported by Hannen et al, who reported that the presence of the $\mathrm{CD}^{+} \mathrm{T}_{\mathrm{H}}$ cells and $\mathrm{CD} 8^{+} \mathrm{T}_{\mathrm{C}}$ cells within the TME is critical to control tumor growth [37]. In addition, MDSCs suppress the activity of T cells and induce apoptosis [38]. Our results show that the lower number of CD4 ${ }^{+} \mathrm{T}_{\mathrm{H}}$ cells and $\mathrm{CD}^{+} \mathrm{T}_{\mathrm{C}}$ cells as well as higher numbers of MDSCs in

A)

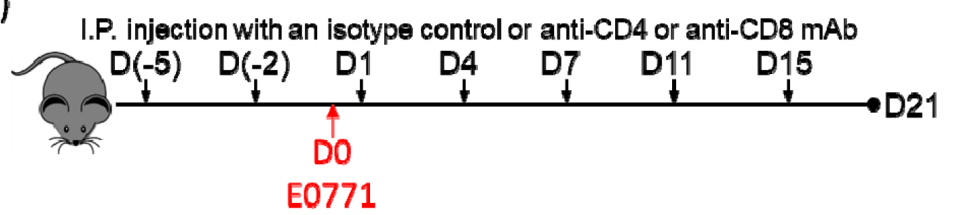

B)

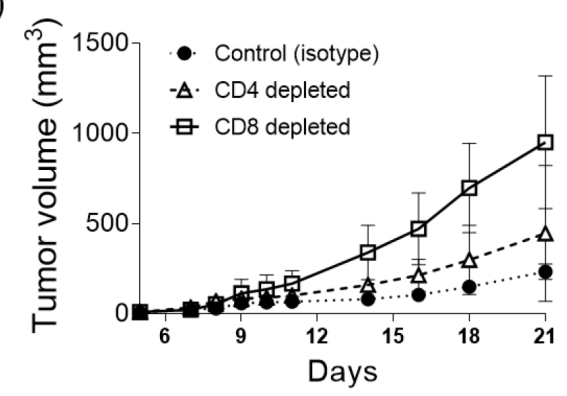

C)

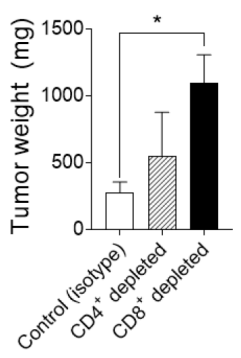

D)

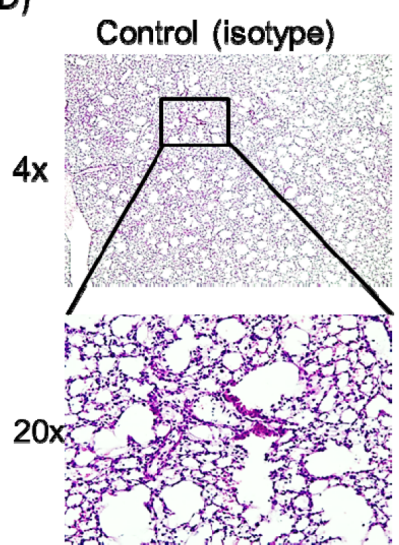

CD4 depleted

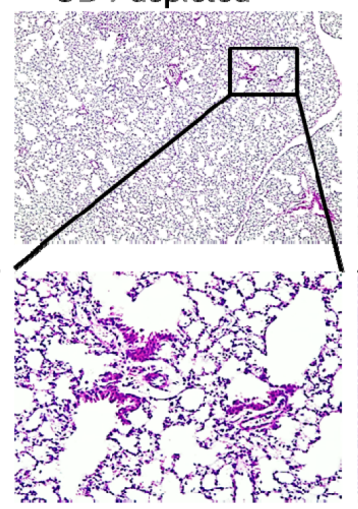

CD8 depleted

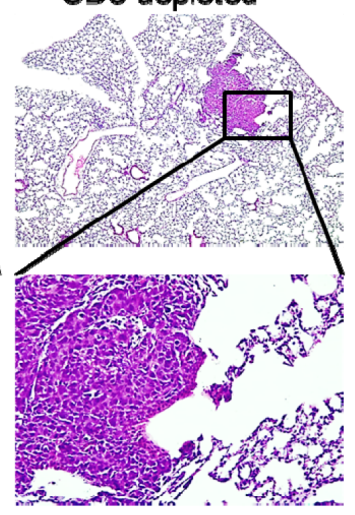

E)

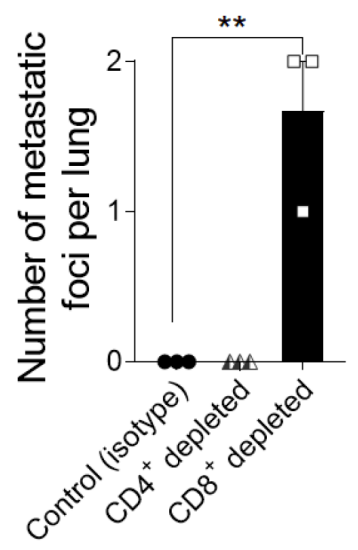

Figure 7: Depletion of $\mathrm{CD8}^{+}$cytotoxic $\mathbf{T}$ cells in periphery leads to increased tumor growth. (A) Diagram showing the scheme for administration of anti-CD4 $(n=3)$ or anti-CD8 $(n=3)$ or an isotype control $(n=3)$ and tumor implantation. (B) Tumor growth was measured by digital caliper and is represented as tumor volume (LxWxWx0.5). (C) Tumors were harvested on day 21 post-implantation and weighed. Data is presented as bar graph, unpaired $t$-test, ${ }^{*} p<0.05$. (D) Representative images of hematoxylin and eosin staining of lung sections collected on day 21 post-tumor-implantation from control (left panels), CD4 depleted (middle panels) and CD8 depleted (right panels) mice. The upper panels are at $4 \mathrm{X}$ magnification, while the lower panels are the 20X magnified images from the indicated solid lined area. (E) Quantification of metastatic foci per H\&E stained lung sections as observed at 20X magnification on day 21 post-implantation. Day-21 post-implantation lungs are from one experiment with $\mathrm{n}=3$, mean $\pm \mathrm{SD}$, unpaired t-test, ${ }^{* *} p<0.01$. 
a pro-tumorigenic environment may lead to the increased growth of tumors in the a2 $\mathrm{V}-\mathrm{KO}$ mice.

To better understand the immune-regulatory factors that contribute to the dynamics of the TME, we performed targeted RNA-Seq. We analyzed 485 genes out of which 144 genes were significantly downregulated while 3 genes were significantly upregulated in a2V-KO TME (Supplementary Figure 2A). The findings from targeted RNA-Seq experiments further support our hypothesis that the TME of $\mathrm{a} 2 \mathrm{~V}-\mathrm{KO}$ mice is pro-tumorigenic (i.e. less inflammatory) than the control TME. The a2 $\mathrm{V}-\mathrm{KO}$ mice TME has significantly lower levels of pro-inflammatory cytokine transcripts (Figure 4A), which correlates very well with lower occurrence of $\mathrm{CD}^{+} \mathrm{T}_{\mathrm{H}}$ cells in the a2 $\mathrm{V}-\mathrm{KO}$ TME. The lower percentage of $\mathrm{CD}^{+} \mathrm{T}_{\mathrm{H}}$ cells and $\mathrm{CD} 8^{+} \mathrm{T}_{\mathrm{C}}$ cells in a2V-KO TME is also reflected by a significant decrease in $\mathrm{T}$ cell- and immune-check-point- related transcripts in a2V-KO TME (Supplementary Figures 3B \& $3 C)$. However, we did not find any significant difference in the transcript level for CD4 between a2V-KO and control TMEs. CD4 is also expressed on macrophages and there is no significant difference between TAM populations of a2 V-KO and control TME (Supplementary Figure 2A). Pro-inflammatory cytokines like TNF- $\alpha$, IFN- $\gamma$ and GM-CSF upregulate death receptors on cancer cells and induce apoptosis $[6,7]$. Our results demonstrate that in comparison to the control TME, there is also a significantly lower level of transcripts of death receptors and cytotoxic effector in the a2V-KO TME (Figures 4B and 4D). These results bolster the idea that the a2 $\mathrm{V}-\mathrm{KO}$ TME is pro-tumorigenic and conducive for tumor growth, as there are significantly less pro-inflammatory cytokines, cytotoxic effector molecules and $\mathrm{T}_{\mathrm{C}}$ cells compared to the control TME. As a group, these factors contribute to a faster growing and larger breast tumor in the a2 $\mathrm{V}-\mathrm{KO}$ mice.

Transcript levels of $A c k r 2, M m p 3$, and $P p b p$ are significantly increased in the a2V-KO TME (Figure $4 \mathrm{E})$. Atypical chemokine receptor 2 or D6 is a decoy receptor or scavenger receptor that sequesters various chemokines by high affinity binding [29, 39, 40]. Higher transcript levels of $A c k r 2$ indicate lower transcript levels of chemokines present in the a2V-KO TME. In fact, this was found to be true (Supplementary Figure 3D). The pro-platelet basic protein or CXCL7 is a chemokine and acts as heparanase [30]. MMP3 is expressed in higher levels breast cancer [41] and involved in mammary carcinogenesis [31]. It has been reported that higher levels of MMP3 is viewed as a marker of unfavorable prognosis in invasive breast cancer [42]. Furthermore, malignant breast cancer cells express higher levels of CXCL7 and it helps in invasion and metastasis [43]. CXCL7 is also important for self-renewal of breast cancer stem cells [44]. The higher expression levels of D6 sequesters available pro-inflammatory chemokines from the a2V-KO TME making it less inflammatory, while higher expression of MMP3 and CXCL7 help tumor cells to degrade extracellular matrix and metastasize. Collectively, these results support our previous findings that the a $2 \mathrm{~V}-\mathrm{KO}$ TME is not inflammatory, and thus is conducive for cancer cell proliferation and metastasis.

The presence of both the $\mathrm{CD}^{+} \mathrm{T}_{\mathrm{H}}$ cells and $\mathrm{CD} 8^{+}$ $\mathrm{T}_{\mathrm{C}}$ cells in the periphery is very important to control tumor progression and metastasis. However, the extent of protection offered by the two major subtypes of $\mathrm{T}$ cells, namely the $\mathrm{CD}^{+} \mathrm{T}_{\mathrm{H}}$ cells and $\mathrm{CD}^{+} \mathrm{T}_{\mathrm{C}}$ cells varies. It has been reported that at different time points, both the $\mathrm{CD}^{+}$ $\mathrm{T}_{\mathrm{H}}$ cells and $\mathrm{CD} 8^{+} \mathrm{T}_{\mathrm{C}}$ cells could have similar or opposing roles during breast cancer progression. At later time points, the composition of $\mathrm{CD}^{+} \mathrm{T}_{\mathrm{H}}$ cells differentiates from a $T_{H} 1$ phenotype to $T_{H} 17$ phenotype, resulting in negative prognostic effects, while the $\mathrm{CD}^{+} \mathrm{T}_{\mathrm{C}}$ cells are the key effector cells that control tumor progression [45, 46]. As shown in the $\mathrm{T}$ cell depletion experiment (Figure 7 ), the lack of $\mathrm{CD}^{+} \mathrm{T}_{\mathrm{C}}$ cells in the periphery had the most effect on tumor growth and metastasis. In contrast, the lack the $\mathrm{CD}^{+} \mathrm{T}_{\mathrm{H}}$ cells had a moderate effect on tumor growth, but not on metastasis. This could be due to the fact that $\mathrm{CD}^{+} \mathrm{T}_{\mathrm{H}}$ cells are instrumental to secrete cytokines that modulate $\mathrm{CD}^{+} \mathrm{T}_{\mathrm{C}}$ cells and NK cells which in turn control tumor cells. Their role however is dispensable as other cells within the TME produce cytokines to modulate the professional killer cells $[6,7]$. It has also been reported that low number $\mathrm{CD}^{+} \mathrm{T}_{\mathrm{C}}$ cells are poor prognostic markers in non-small cell lung carcinoma and colorectal cancer development in humans [47] [48]. The number of metastatic foci in lungs of mice depleted of $\mathrm{CD}^{+} \mathrm{T}_{\mathrm{C}}$ cells (Figure 7E) is less than a2V-KO mice (Figure 5C) might be due to the fact that other cell types are also affected (Figure 3A and Supplementary Figure 2C).

To our knowledge, this is the first report that demonstrates that the deletion of HSC-associated a2 V has a severe effect on the distribution of $\alpha \beta\left(\mathrm{CD} 4^{+}\right.$and $\left.\mathrm{CD}^{+}\right)$ $\mathrm{T}$ cells in the peripheral blood and spleen (Figures $6 \mathrm{~A}$ and $6 \mathrm{~B})$. In contrast, the distribution of other lymphoid cells like B cells and myeloid cells (data not shown) seems to be increased to maintain homeostasis. The exact mechanism for this defect in distribution of $\alpha \beta \mathrm{T}$ cells is currently unknown. Therefore, we analyzed the distribution of $\alpha \beta$ $\mathrm{T}$ cells in the thymus and bone marrow and observed a defect in their development (Figures 6C and 6D). $\mathrm{V}$-ATPase is a known $\mathrm{pH}$ sensor and it regulates $\mathrm{pH}$ of intracellular organelles and cytoplasm, controls endocytic traffic, regulates protein processing and degradation, and acts as a scaffold for protein-protein interactions [49]. Hence, any defect in a $2 \mathrm{~V}$ will also result in significant changes in the above mentioned mechanisms. Based on previous studies from our group, we are currently investigating various pathways to understand the reduced occurrence of $\alpha \beta \mathrm{T}$ cells in the bone marrow and thymus. Previously, it was shown that a2V deletion in the host mammary epithelial cells leads to defective 
glycosylation of extracellular matrix proteins due to the relocation of glycosyltransferase enzyme to endosomes [28]. We also have previously demonstrated that deletion of a $2 \mathrm{~V}$ in breast cancer and ovarian cancer cells leads to enhanced cell death by autophagy and apoptotic pathways, respectively, by increasing cytosolic pH [16, 50]. T cells originate in bone marrow, but develop and mature in thymus where they undergo positive and negative selection. During these selection processes a lot of T cells undergo apoptosis while relatively low number of mature $\mathrm{T}$ cells egress to circulation [51]. Furthermore, a defect in glycosylation in $\mathrm{T}$ cells block $\mathrm{T}$ cell progenitor renewal and clonal expansion [52]. Therefore, investigating cell death pathways and glycosylation pathways in the bone marrow and thymus might hold clues for solving this mystery.

In summary, this is the first time we demonstrate that the deletion of a2V from the HSC has a dramatic effect on the host immune system through reduction of $\mathrm{CD}^{+} \mathrm{T}_{\mathrm{H}}$ cells and $\mathrm{CD}^{+} \mathrm{T}_{\mathrm{C}}$ cells in lymphoid organs and periphery. This reduction of immune cell populations in the periphery and TME promoted necrotic breast tumors in the a2V-KO mice. The pro-tumorigenic TME of a2 $\mathrm{V}-\mathrm{KO}$ mice have significantly less pro-inflammatory cytokines,

\section{Control (WT)}

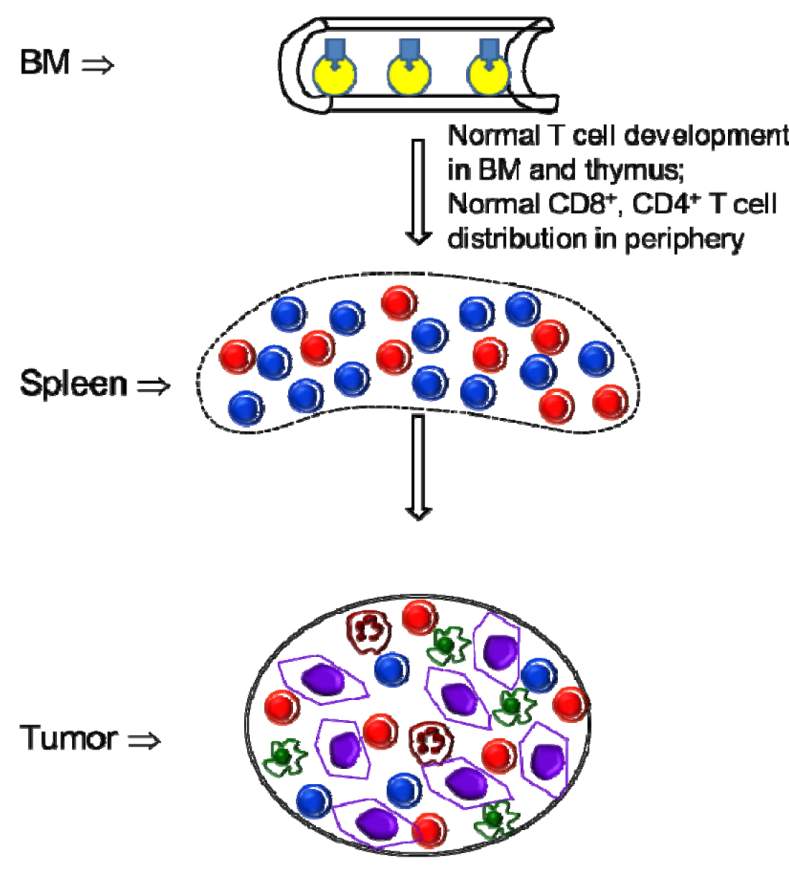

Pro-inflammatory TME:

$\uparrow$ Pro-inflammatory cytokines

$\uparrow$ Pro-apoptotic death receptors

$\uparrow$ Cytotoxic effector molecules

$\downarrow$ ECM modifying enzymes
a2V-KO

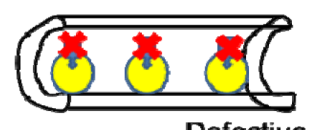

Defective T cell development

in $\mathrm{BM}$ and thymus;

Fewer $\mathrm{CD}^{+}, \mathrm{CD}^{+} \mathrm{T}$ cells in

spleen and periphery

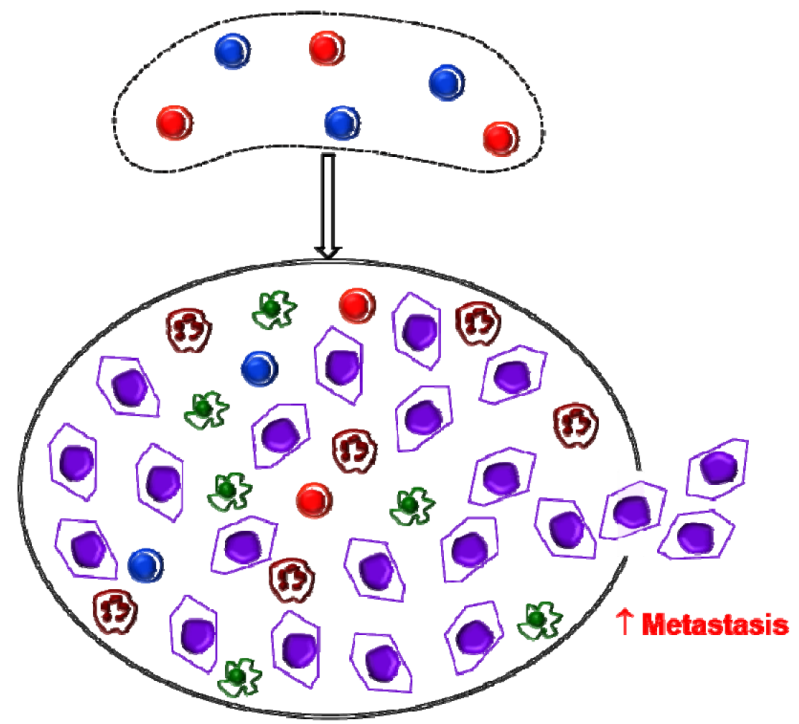

Pro-tumorigenic TME:

$\downarrow$ Pro-inflammatory cytokines

$\downarrow$ Pro-apoptotic death receptors

$\downarrow$ Cytotoxic effector molecules

$\uparrow$ ECM modifying enzymes

\section{Hematopoietic stem cell; $\mathrm{CD8} 8^{+} \mathrm{T}_{\mathrm{C}}$ cell; $\bigcirc \mathrm{CD4}^{+} \mathrm{T}_{\mathrm{H}}$ cell; $\bigcirc$ Tumor cell (33) Myeloid derived suppressor cell; 3 Tumor associated macrophage}

Figure 8: Proposed model and mode of action. The deletion of a2V from the HSC results in a defect in $\alpha \beta$ T production in the $\mathrm{BM}$ and thymus, which results in drastic reduction of $\alpha \beta \mathrm{T}$ cells in the periphery as represented in spleen. After tumor implantation, this reduction of $\alpha \beta \mathrm{T}$ cells promotes highly necrotic and metastatic breast tumors in the a2V-KO mice. The pro-tumorigenic TME of a2 V-KO mice have lower levels of pro-inflammatory cytokines, death ligands, death receptors, cytotoxic effector molecules, $\mathrm{CD}^{+} \mathrm{T}_{\mathrm{H}}$ cells, $\mathrm{CD} 8^{+}$ $\mathrm{T}_{\mathrm{C}}$ cells, higher levels of ECM modifying enzymes, and higher number of MDSCs compared to the pro-inflammatory TME of control mice. This pro-tumorigenic, immuno-suppressive microenvironment is conducive for faster tumor growth and allows tumor cells to metastasize. 
death ligands, death receptors, effector molecules, CD4 ${ }^{+}$ $\mathrm{T}_{\mathrm{H}}$ cells and $\mathrm{CD}^{+} \mathrm{T}_{\mathrm{C}}$ cells compared to the control mice. Depletion of $\mathrm{CD}^{+} \mathrm{T}_{\mathrm{C}}$ cells from the periphery of control mice also led to larger and metastatic tumors (Figure 8). Collectively, our findings show that V-ATPase activity in $\mathrm{HSC}$ is required for proper development of $\mathrm{T}$ cells and it can affect the progression of breast cancer. Further studies are required to decipher the mechanisms by which V-ATPase controls T cell development.

\section{MATERIALS AND METHODS}

\section{Generation of a2 V- knock out (a2V-KO) mice}

All animal experiments were performed in the biological resource facility of Rosalind Franklin University of Medicine and Science (RFUMS) in accordance with the guidelines provided by the Institutional Animal Care and Use Committee (IACUC) of the National Institute of Health.

ATP6v0a2 floxed ( $\mathrm{a} 2 \mathrm{~V}^{\mathrm{fl} / \mathrm{fl}}$ ) mice were generated as described earlier [53]. Vav1 $1^{\mathrm{CreTg} / 0}$ hemizygous mice were obtained from Jackson Laboratories (stock\# 008610, Jackson Laboratories, Bar Harbor, ME, USA). To generate a2V-conditional knock out mice, a2 $\mathrm{V}^{\mathrm{fl} / \mathrm{fl}}$ mice were crossed with Vav1 $1^{\mathrm{CreTg} / 0}$ hemizygous mice. The resulting $\mathrm{a} 2 \mathrm{~V}^{\mathrm{fl} / 0} \mathrm{Vav} 1^{\mathrm{CreTg} / 0}$ mice were further backcrossed with $\mathrm{a} 2 \mathrm{~V}^{\mathrm{fl} / \mathrm{fl}}$ (control) mice to generate a2 $\mathrm{V}^{\mathrm{fl} / \mathrm{fl}} \mathrm{Vav} 1^{\mathrm{CreTg} / 0}(\mathrm{a} 2 \mathrm{~V}$ $\mathrm{KO})$ mice. Both control and $\mathrm{a} 2 \mathrm{~V}-\mathrm{KO}$ mice are of the same $\mathrm{C} 57 \mathrm{BL} / 6$ background. The presence of the a2 $\mathrm{V}^{\mathrm{fl} / \mathrm{fl}}$ gene was confirmed by PCR using the following primer pair: forward primer 5'-AGGGTGGTGTCCTTTCACTCT-3' and reverse primer 5'-ATCCCCAGGATCCACGCAT-3'. The presence of $\mathrm{Vav}^{\mathrm{Cre}}$ transgene was confirmed by the following primer pair: forward primer 5'-AGATGCCAGGACATCAGGAACCTG-3' and reverse primer 5' - ATCAGCCACACCAGACACAGAGATC-3' (IDT, IL, USA). The PCR conditions were followed as described in Jackson Laboratories website (Jackson Laboratories). The control and a2 $\mathrm{V}-\mathrm{KO}$ mice were followed up to 40 weeks of age and monitored for viability, fertility, growth or any externally visible abnormality.

\section{Tumor generation and antibody treatment}

Breast tumors were generated as described earlier [19]. Briefly, $0.5 \times 10^{6}$ of syngeneic E0771 (murine mammary adenocarcinoma) cells were suspended in $50 \mu \mathrm{l}$ HBSS and mixed with $50 \mu$ l Corning Matrigel HC. This cell and Matrigel mixture was implanted into the $4^{\text {th }}$ mammary fat-pad of 8 week old control or a $2 \mathrm{~V}-\mathrm{KO}$ female mice. For all experiments, littermate mice were used. The tumors were allowed to grow until day 14 post-injection and the length and width of the tumor was measured every alternate day. After 14 days post-implantation, the mice were euthanized, tumors were surgically removed, washed in PBS, weighed, and processed for further use. Tumor volume was measured by using the following formula: ( $\mathrm{LxWxWx} 0.5)$, where $\mathrm{L}=$ the longer measurement and $\mathrm{W}=$ the shorter measurement. Lungs were collected after perfusion with $10 \mathrm{ml}$ of PBS and fixed in $16 \%$ formaldehyde solution (W/V).

To deplete total $\mathrm{CD}^{+} \mathrm{T}_{\mathrm{H}}$ cells and $\mathrm{CD}^{+} \mathrm{T}_{\mathrm{C}}$ cell populations, $8 \mathrm{wk}$ old female control mice were injected (i.p.) with $250 \mu \mathrm{g}$ of anti-CD4 (clone-GK1.5), or antiCD8 (clone-2.43), or isotype control (clone-LTF-2) from BioXcell (West Lebanon, $\mathrm{NH}$ ). The mice received antibodies on the following days: D(-5), D(-1), D3, D7, D11 and D15. Tumor growth was measured until D21 post-implantation and mice were euthanized on that day, tumors were weighed and lungs were collected to examine for any metastasis by histology.

\section{RNA extraction and reverse transcription}

RNA was isolated using Qiagen's RNAeasy Mini Kit (Qiagen, CA). RNA was quantified using a Nanodrop (Thermo Fisher, CA). Reverse transcription was performed with $1 \mu \mathrm{g}$ of total RNA using Transcriptor First Strand cDNA Synthesis Kit (Roche, Switzerland).

\section{Quantitative reverse transcription PCR (qRT-PCR)}

Fifty nanograms of RNA-equivalent cDNA was used for qRT-PCR using TaqMan Fast Advanced Master Mix (Applied Biosystems, Carlsbad, CA) and read with StepOnePlus real-time PCR instrument (Applied Biosystems). Validated TaqMan primer mix for a1V (Mm00444210_m1 Atp6v0a), a2V (Mm00441838_m1 Atp6v0a), a3V (Mm00469406_m1 Tcirg1) and $\overline{\mathrm{a}} 4 \mathrm{~V}$ (Mm00459882_m1 Atp6v0a) were obtained from Applied Biosystems. The expression of test genes was normalized using internal house-keeping gene, GAPDH (4352339E1208041).

\section{Targeted RNA-Seq via next-generation sequencing (NGS)}

Next-generation sequencing (NGS) Library preparation was performed using Qiagen's targeted "Mouse Inflammation and Immunity Transcriptome" panels containing probes for 485 genes as described earlier [54]. Briefly, cDNA was prepared from $400 \mathrm{ng}$ of tumor RNA and unique molecular tags of 12 nucleotide length were incorporated into $20 \mathrm{ng}$ cDNA via gene specific primer extension. After PCR purification using magnetic beads, the barcoded cDNA was amplified using gene specific primers. The purified DNA was again amplified through a second PCR reaction to insert index sequences that are unique to each sample. The completed library was loaded into Illumina's reagent cartridge (150 cycle v3) and 
sequenced on a standard flow cell with custom sequencing primers provided by Qiagen.

Sequencing quality controls, including cluster density, total reads, and percent reads reaching Q30 were all within optimal ranges provided by Illumina. In addition, secondary quality controls provided by Qiagen's targeted RNA-Seq software that reads and quantifies the sequencing files were all within acceptable ranges. The FASTQ files obtained from the sequencing runs were uploaded to Qiagen's GeneRead DNAseq variant calling service. The data was then exported into a format that provides the total unique molecular barcode sequencing reads for each gene. All reads were normalized to 8 internal control housekeeping genes after screening negative for genomic DNA contamination. Mann-Whitney's $U$-test was performed on the normalized data and expressed as "normalized expression" for the bar diagrams.

\section{Flow cytometry}

Tumors were collected from tumor bearing mice on D14 after tumor inoculation and processed to get single cell suspension. Briefly, tumors were chopped to $1 \mathrm{~mm}$ size and incubated at $37^{\circ} \mathrm{C}$ with Collagenase IV (Worthington) and DNAse I (Sigma) for 2 hours while being rotated in RPMI medium without serum. The collagenase was neutralized with $10 \%$ fetal calf serum, washed twice with normal RPMI, filtered through $100 \mu \mathrm{M}$ cell sieve. The cell pellets from tumors were subjected to red blood cell lysing and filtered through a $70 \mu \mathrm{M}$ cell sieve. These cells were used to isolate the $\mathrm{CD} 45^{+}$cells using magnetically activated cell sorting (MACS, CD45 isolation kit, Miltenyi). Spleens, thymus, bone marrow and blood were collected from non-tumor bearing mice. Spleen, thymus and flushed bone marrow cells were mechanically disrupted to get a single cell suspension. These single cells and blood were subjected to red blood lysis and filtered through a $70 \mu \mathrm{M}$ cell sieve. The live, single cells were counted with trypan blue manually by a hemocytometer.

The single cells were subjected to live-dead staining (Live dead green kit, Applied Biosystems) and subsequently labeled with antibodies for flow cytometry for $30 \mathrm{~min}$ at $4^{\circ} \mathrm{C}$. The following antibody cocktails were used: T cell cocktail containing antibodies against CD19, CD3, NKp46, TCR $\gamma \delta$, CD4, and CD8 $\beta$; Myeloid cell cocktail containing antibodies for CD11b, GR1 or Ly6G, and F4/80. After washing in FACS rinse buffer, cells were fixed in $16 \%$ formaldehyde solution (W/V) for 20 min, washed again and resuspended in FACS rinse buffer (Biolegend). To identify different cell populations, cells were acquired by LSR II (BD) and analyzed by FlowJo software (Treestar, USA).

For analysis of lymphoid cells, live cells were gated on singlets (FSC-H vs FSC-A). The live cells further gated on expression of CD19 and CD3 and 3 gates are drawn. The $\mathrm{CD}^{+} 9^{+} \mathrm{CD}^{-}{ }^{-}$gate, $\mathrm{CD}^{-}{ }^{-} \mathrm{CD} 3^{-}$gate and $\mathrm{CD}^{-} \mathrm{CD}^{-}{ }^{+}$ gate to represent $\mathrm{B}$, non- $\mathrm{B}$ non- $\mathrm{T}$ and $\mathrm{T}$ cells, respectively.
The non-B non- $\mathrm{T}$ gate was further analyzed for expression of NKp46 (FSC vs NKp46) and the CD19-CD3-NKp46 ${ }^{+}$ cells were designated as NK cells. The $\mathrm{T}$ cells were further analyzed for $\gamma \delta$ TCR expression. The CD19-CD3 ${ }^{+} \gamma \delta \mathrm{TCR}^{+}$ and $\mathrm{CD}^{-} 9^{-} \mathrm{CD}^{+} \gamma \delta \mathrm{TCR}^{-}$populations were designated as $\gamma \delta$ T cells and $\alpha \beta$ T cells, respectively. The $\mathrm{CD}^{-} 9^{-} \mathrm{CD}^{+} \gamma \delta$ TCR $^{-} \alpha \beta$ T cell populations were further analyzed for the surface expression of CD4 or CD8. The $\mathrm{CD}^{-} 9^{-} \mathrm{CD}^{+} \gamma \delta$ $\mathrm{TCR}^{-} \mathrm{CD} 4^{+}$and $\mathrm{CD} 19-\mathrm{CD}^{+} \gamma \delta \mathrm{TCR}^{-} \mathrm{CD} 8^{+}$cells were labeled as $\mathrm{CD}^{+} \mathrm{T}_{\mathrm{H}}$ cells or $\mathrm{CD} 8^{+} \mathrm{T}_{\mathrm{C}}$ cells, respectively. For analysis of myeloid cells, live cells were gated on singlets (FSC-H vs FSC-A). The live cells further gated for expression of CD11b. The CD11b cells were selected and further analyzed for expression of GR1 or Ly6G or F4/80 and were labeled as MDSC or TAN or macrophages, respectively.

\section{Histology and immunofluorescence analysis}

Tumors and lungs were fixed in $16 \%$ paraformaldehyde solution (W/V) for 48 hour before embedding in paraffin. The paraffin embedded tissue blocks were sectioned $5 \mu \mathrm{M}$ thick, deparaffinized in xylene, stained with Mayer's hematoxylin and $0.1 \%$ eosin, affixed coverslips with Permount mounting medium and visualized using a Leica ICC 50W light microscope (Leica Biosystems, Wetzlar, Germany).

For Immunofluorescence analysis (IFA) antigen retrieval was carried out on the deparaffinized sections by boiling in sodium citrate buffer ( $\mathrm{pH} \mathrm{6.0).} \mathrm{The} \mathrm{tissue}$ sections were blocked to reduce background non-specific staining by blocking with 5\% BSA and were incubated overnight with primary antibodies at $4^{\circ} \mathrm{C}$. After washing with PBST, sections were incubated for 30 minutes with AF488-conjugated secondary antibodies at room temperature. Again after washing with PBST, sections were mounted using ProLong Diamond antifade mountant with DAPI (Applied Biosystems). After affixing coverslips, the slides were visualized with a Nikon EclipseTE2000-S fluorescence microscope (Nikon, Tokyo, Japan).

Freshly isolated hematopoietic stem cells (HSCs) were similarly processed for IFA in an Eppendorf tube, with exception to the antigen retrieval step. After staining with AF488-conjugated secondary antibody, the cells were spread on slides by cytospin, mounted as before with DAPI and visualized with a Nikon EclipseTE2000-S fluorescence microscope.

\section{Cell line and tissue samples}

Murine mammary adenocarcinoma, E0771 cells (CH3 Biosystems, Amherst, NY, USA) which is syngeneic to $\mathrm{C} 57 \mathrm{BL} / 6$ mice, were cultured as a monolayer in complete RPMI 1640 (Applied Biosystems) media supplemented with $10 \%$ fetal bovine serum, $100 \mathrm{U} / \mathrm{ml}$ penicillin, $100 \mathrm{U} / \mathrm{ml}$ streptomycin and $10 \mathrm{mM}$ HEPES buffer at $37^{\circ} \mathrm{C}$ in a humidified $5 \% \mathrm{CO}_{2}$ incubator. 
Hematopoietic stem cells (HSCs) were isolated from mouse bone marrow. Both tibia and femur were collected from each leg of mice and the bone marrow was flushed out using DPBS. After lysing red blood cells, the HSCs were isolated using EasySep Mouse Hematopoietic Progenitor Cell Isolation Kit (Stem Cell Technologies, Canada) according to the manufacturer's protocol. The purity of the pre- and post-sorted cells was examined by flow-cytometry using a cocktail of CD11b, CD3, CD19, GR1, B220, and Ter119 antibodies (Biolegend).

\section{Statistical analysis}

All data are represented as mean \pm SEM unless stated otherwise. Mann-Whitney $U$ test or unpaired $t$-test was used to calculate the statistical significance between groups as specified in the figure legends. Significance was set at $p<0.05$. Analysis was performed using GraphPad Prism 5 software (GraphPad Prism Software Inc., La Jolla, CA).

\section{Abbreviations}

a2V: a2 isoform of vacuolar ATPase; HSC: Hematopoietic Stem Cell; KO: Knock out; MDSC: Myeloid derived suppressor cell; TAM: Tumor associated macrophage; TAN: Tumor associated neutrophil; $\mathrm{T}_{\mathrm{H}}$ cell: $\mathrm{T}$ helper cell; $\mathrm{T}_{\mathrm{C}}$ cell: Cytotoxic $\mathrm{T}$ cell; TME: Tumor micro environment.

\section{Author contributions}

M.S conceived, designed and performed experiments, analyzed results and wrote the manuscript. G.K.K, M.Y.B, S.A.I, A.K, and S.F performed experiments and participated in data organization. K.S did histopathological analysis of tumor sections. K.D.B was involved with study design, data interpretation, manuscript editing and allocating funds for the project. All authors read and approved the manuscript.

\section{ACKNOWLEDGMENTS}

We thank Robert Dickinson for technical assistance at Flow Cytometry Core Facility of Rosalind Franklin University of Science and Medicine, North Chicago, IL, USA.

\section{CONFLICTS OF INTEREST}

The authors declare no conflicts of interest.

\section{FUNDING}

This work was supported by grants from the Clinical Immunology Laboratory, Rosalind Franklin University of Science and Medicine, North Chicago, IL, USA.

\section{REFERENCES}

1. Gu-Trantien C, Loi S, Garaud S, Equeter C, Libin M, de Wind A, Ravoet M, Le Buanec H, Sibille C, ManfouoFoutsop G, Veys I, Haibe-Kains B, Singhal SK, et al. CD4(+) follicular helper $\mathrm{T}$ cell infiltration predicts breast cancer survival. J Clin Invest. 2013; 123:2873-92. https:// doi.org/10.1172/JCI67428.

2. Black MM. Immunopathology of breast cancer. Pathobiol Annu. 1977; 7:213-30.

3. Aaltomaa S, Lipponen P, Eskelinen M, Kosma VM, Marin S, Alhava E, Syrjanen K. Lymphocyte infiltrates as a prognostic variable in female breast cancer. Eur J Cancer. 1992; 28A: 859-64.

4. Balkwill FR, Capasso M, Hagemann T. The tumor microenvironment at a glance. J Cell Sci. 2012; 125:55916. https://doi.org/10.1242/jcs.116392.

5. Janssen EM, Lemmens EE, Wolfe $T$, Christen U, von Herrath MG, Schoenberger SP. CD4 $+\mathrm{T}$ cells are required for secondary expansion and memory in CD8+ T lymphocytes. Nature. 2003; 421:852-6. https://doi. org/10.1038/nature01441.

6. Dadmarz R, Sgagias MK, Rosenberg SA, Schwartzentruber DJ. CD4+ T lymphocytes infiltrating human breast cancer recognise autologous tumor in an MHC-class-II restricted fashion. Cancer Immunol Immunother. 1995; 40:1-9.

7. Gisterek I, Frydecks I, Swiatoniowski I, Fidler I, Kornafel I. Tumor-infiltrating CD4 and CD8 T lymphocytes in breast cancer. Rep Pract Oncol Radiother. 2008; 13:206-9.

8. Chemnitz JM, Parry RV, Nichols KE, June CH, Riley JL. SHP-1 and SHP-2 associate with immunoreceptor tyrosine-based switch motif of programmed death 1 upon primary human $\mathrm{T}$ cell stimulation, but only receptor ligation prevents T cell activation. J Immunol. 2004; 173:945-54.

9. Movahedi K, Guilliams M, Van den Bossche J, Van den Bergh R, Gysemans C, Beschin A, De Baetselier P, Van Ginderachter JA. Identification of discrete tumor-induced myeloid-derived suppressor cell subpopulations with distinct T cell-suppressive activity. Blood. 2008; 111:423344. https://doi.org/10.1182/blood-2007-07-099226.

10. Nagaraj S, Schrum AG, Cho HI, Celis E, Gabrilovich DI. Mechanism of $\mathrm{T}$ cell tolerance induced by myeloid-derived suppressor cells. J Immunol. 2010; 184:3106-16. https://doi. org/10.4049/jimmunol.0902661.

11. Bronte V, Brandau S, Chen SH, Colombo MP, Frey AB, Greten TF, Mandruzzato S, Murray PJ, Ochoa A, OstrandRosenberg S, Rodriguez PC, Sica A, Umansky V, et al. Recommendations for myeloid-derived suppressor cell nomenclature and characterization standards. Nat Commun. 2016; 7:12150. https://doi.org/10.1038/ncomms 12150 .

12. Lugini L, Matarrese P, Tinari A, Lozupone F, Federici C, Iessi E, Gentile M, Luciani F, Parmiani G, Rivoltini L, Malorni W, Fais S. Cannibalism of live lymphocytes by human metastatic but not primary melanoma cells. Cancer 
Res. 2006; 66:3629-38. https://doi.org/10.1158/0008-5472. CAN-05-3204.

13. Calcinotto A, Filipazzi P, Grioni M, Iero M, De Milito A, Ricupito A, Cova A, Canese R, Jachetti E, Rossetti M, Huber V, Parmiani G, Generoso L, et al. Modulation of microenvironment acidity reverses anergy in human and murine tumor-infiltrating $\mathrm{T}$ lymphocytes. Cancer Res. 2012; 72:2746-56. https://doi.org/10.1158/0008-5472. CAN-11-1272.

14. Pilon-Thomas S, Kodumudi KN, El-Kenawi AE, Russell S, Weber AM, Luddy K, Damaghi M, Wojtkowiak JW, Mule JJ, Ibrahim-Hashim A, Gillies RJ. Neutralization of Tumor Acidity Improves Antitumor Responses to Immunotherapy. Cancer Res. 2016; 76:1381-90. https://doi. org/10.1158/0008-5472.CAN-15-1743.

15. Forgac M. Vacuolar ATPases: rotary proton pumps in physiology and pathophysiology. Nat Rev Mol Cell Biol. 2007; 8:917-29. https://doi.org/10.1038/nrm2272.

16. Kulshrestha A, Katara GK, Ginter J, Pamarthy S, Ibrahim SA, Jaiswal MK, Sandulescu C, Periakaruppan R, Dolan J, Gilman-Sachs A, Beaman KD. Selective inhibition of tumor cell associated Vacuolar-ATPase 'a2' isoform overcomes cisplatin resistance in ovarian cancer cells. Mol Oncol. 2016; 10:789-805. https://doi.org/10.1016/j. molonc.2016.01.003.

17. Smith GA, Howell GJ, Phillips C, Muench SP, Ponnambalam S, Harrison MA. Extracellular and Luminal pH Regulation by Vacuolar H+-ATPase Isoform Expression and Targeting to the Plasma Membrane and Endosomes. J Biol Chem. 2016; 291:8500-15. https://doi.org/10.1074/jbc. M116.723395.

18. Stransky L, Cotter K, Forgac M. The Function of V-ATPases in Cancer. Physiol Rev. 2016; 96:1071-91. https://doi. org/10.1152/physrev.00035.2015.

19. Katara GK, Kulshrestha A, Jaiswal MK, Pamarthy S, Gilman-Sachs A, Beaman KD. Inhibition of vacuolar ATPase subunit in tumor cells delays tumor growth by decreasing the essential macrophage population in the tumor microenvironment. Oncogene. 2016; 35:1058-65. https://doi.org/10.1038/onc.2015.159.

20. Breton S, Brown D. Regulation of luminal acidification by the V-ATPase. Physiology (Bethesda). 2013; 28:318-29. https://doi.org/10.1152/physiol.00007.2013.

21. Guillard M, Dimopoulou A, Fischer B, Morava E, Lefeber DJ, Kornak U, Wevers RA. Vacuolar H+-ATPase meets glycosylation in patients with cutis laxa. Biochim Biophys Acta. 2009; 1792:903-14. https://doi.org/10.1016/j. bbadis.2008.12.009.

22. Derks RA, Beaman KD. Regeneration and tolerance factor prevents bystander T-cell death associated with human immunodeficiency virus infection. Clin Diagn Lab Immunol. 2004; 11:835-40. https://doi.org/10.1128/ CDLI.11.5.835-840.2004.
23. Ntrivalas E, Derks R, Gilman-Sachs A, Kwak-Kim J, Levine R, Beaman K. Novel role for the N-terminus domain of the a 2 isoform of vacuolar ATPase in interleukin-1beta production. Hum Immunol. 2007; 68:469-77. https://doi. org/10.1016/j.humimm.2007.02.010.

24. Gilman-Sachs A, Tikoo A, Akman-Anderson L, Jaiswal M, Ntrivalas E, Beaman K. Expression and role of a2 vacuolarATPase (a2V) in trafficking of human neutrophil granules and exocytosis. J Leukoc Biol. 2015; 97:1121-31. https:// doi.org/10.1189/jlb.3A1214-620RR.

25. Kwong C, Gilman-Sachs A, Beaman K. Tumor-associated a2 vacuolar ATPase acts as a key mediator of cancer-related inflammation by inducing pro-tumorigenic properties in monocytes. J Immunol. 2011; 186:1781-9. https://doi. org/10.4049/jimmunol.1002998.

26. Katara GK, Jaiswal MK, Kulshrestha A, Kolli B, GilmanSachs A, Beaman KD. Tumor-associated vacuolar ATPase subunit promotes tumorigenic characteristics in macrophages. Oncogene. 2014; 33:5649-54. https://doi. org/10.1038/onc.2013.532.

27. Ibrahim SA, Katara GK, Kulshrestha A, Jaiswal MK, Amin MA, Beaman KD. Breast cancer associated a2 isoform vacuolar ATPase immunomodulates neutrophils: potential role in tumor progression. Oncotarget. 2015; 6:33033-45. https://doi.org/10.18632/oncotarget.5439.

28. Katara GK, Kulshrestha A, Mao L, Wang X, Sahoo M, Ibrahim S, Pamarthy S, Suzue K, Shekhawat GS, Gilman-Sachs A, Beaman KD. Mammary epitheliumspecific inactivation of V-ATPase reduces stiffness of extracellular matrix and enhances metastasis of breast cancer. Mol Oncol. 2018; 12:208-23. https://doi. org/10.1002/1878-0261.12159.

29. Graham GJ, Locati M, Mantovani A, Rot A, Thelen M. The biochemistry and biology of the atypical chemokine receptors. Immunol Lett. 2012; 145:30-8. https://doi. org/10.1016/j.imlet.2012.04.004.

30. Hoogewerf AJ, Leone JW, Reardon IM, Howe WJ, Asa D, Heinrikson RL, Ledbetter SR. CXC chemokines connective tissue activating peptide-III and neutrophil activating peptide-2 are heparin/heparan sulfate-degrading enzymes. J Biol Chem. 1995; 270:3268-77.

31. Sternlicht MD, Lochter A, Sympson CJ, Huey B, Rougier JP, Gray JW, Pinkel D, Bissell MJ, Werb Z. The stromal proteinase MMP3/stromelysin-1 promotes mammary carcinogenesis. Cell. 1999; 98:137-46.

32. Hinton A, Sennoune SR, Bond S, Fang M, Reuveni M, Sahagian GG, Jay D, Martinez-Zaguilan R, Forgac M. Function of a subunit isoforms of the V-ATPase in $\mathrm{pH}$ homeostasis and in vitro invasion of MDA-MB231 human breast cancer cells. J Biol Chem. 2009; 284:16400-8. https://doi.org/10.1074/jbc.M901201200.

33. Capecci J, Forgac M. The function of vacuolar ATPase (V-ATPase) a subunit isoforms in invasiveness of MCF10a and MCF10CA1a human breast cancer cells. J Biol 
Chem. 2013; 288:32731-41. https://doi.org/10.1074/jbc. M113.503771.

34. Lalor PA, Stall AM, Adams S, Herzenberg LA. Permanent alteration of the murine Ly-1 B repertoire due to selective depletion of Ly-1 B cells in neonatal animals. Eur J Immunol. 1989; 19:501-6. https://doi.org/10.1002/eji.1830190314.

35. Ewens A, Mihich E, Ehrke MJ. Distant metastasis from subcutaneously grown E0771 medullary breast adenocarcinoma. Anticancer Res. 2005; 25:3905-15.

36. Lester S, Cotran R. (1999). The Breast. (Philadelphia: W.B. Saunders and Company).

37. Haanen JB, Baars A, Gomez R, Weder P, Smits M, de Gruijl TD, von Blomberg BM, Bloemena E, Scheper RJ, van Ham SM, Pinedo HM, van den Eertwegh AJ. Melanoma-specific tumor-infiltrating lymphocytes but not circulating melanomaspecific T cells may predict survival in resected advancedstage melanoma patients. Cancer Immunol Immunother. 2006; 55:451-8. https://doi.org/10.1007/s00262-005-0018-5.

38. Talmadge JE, Gabrilovich DI. History of myeloid-derived suppressor cells. Nat Rev Cancer. 2013; 13:739-52. https:// doi.org/10.1038/nrc3581.

39. Fra AM, Locati M, Otero K, Sironi M, Signorelli P, Massardi ML, Gobbi M, Vecchi A, Sozzani S, Mantovani A. Cutting edge: scavenging of inflammatory $\mathrm{CC}$ chemokines by the promiscuous putatively silent chemokine receptor D6. J Immunol. 2003; 170:2279-82.

40. Nibbs RJ, Wylie SM, Yang J, Landau NR, Graham GJ. Cloning and characterization of a novel promiscuous human beta-chemokine receptor D6. J Biol Chem. 1997; 272:32078-83.

41. Radisky ES, Raeeszadeh-Sarmazdeh M, Radisky DC. Therapeutic Potential of Matrix Metalloproteinase Inhibition in Breast Cancer. J Cell Biochem. 2017; 118:3531-48. https://doi.org/10.1002/jcb.26185.

42. Ghilardi G, Biondi ML, Caputo M, Leviti S, DeMonti M, Guagnellini E, Scorza R. A single nucleotide polymorphism in the matrix metalloproteinase-3 promoter enhances breast cancer susceptibility. Clin Cancer Res. 2002; 8:3820-3.

43. Tang Z, Yu M, Miller F, Berk RS, Tromp G, Kosir MA. Increased invasion through basement membrane by CXCL7-transfected breast cells. Am J Surg. 2008; 196:6906. https://doi.org/10.1016/j.amjsurg.2008.08.001.

44. Liu S, Ginestier C, Ou SJ, Clouthier SG, Patel SH, Monville F, Korkaya H, Heath A, Dutcher J, Kleer CG, Jung Y, Dontu G, Taichman R, et al. Breast cancer stem cells are regulated by mesenchymal stem cells through cytokine networks. Cancer Res. 2011; 71:614-24. https://doi.org/10.1158/00085472.CAN-10-0538.
45. Huang Y, Ma C, Zhang Q, Ye J, Wang F, Zhang Y, Hunborg P, Varvares MA, Hoft DF, Hsueh EC, Peng G. CD4+ and CD8+ $\mathrm{T}$ cells have opposing roles in breast cancer progression and outcome. Oncotarget. 2015; 6:17462-78. https://doi.org/10.18632/oncotarget.3958.

46. Wilke CM, Kryczek I, Wei S, Zhao E, Wu K, Wang G, Zou W. Th17 cells in cancer: help or hindrance? Carcinogenesis. 2011; 32:643-9. https://doi.org/10.1093/carcin/bgr019.

47. Onion D, Isherwood M, Shridhar N, Xenophontos M, Craze ML, Day LJ, Garcia-Marquez MA, Pineda RG, Reece-Smith AM, Saunders JH, Duffy JP, Argent RH, Grabowska AM. Multicomponent analysis of the tumour microenvironment reveals low CD8 T cell number, low stromal caveolin-1 and high tenascin- $\mathrm{C}$ and their combination as significant prognostic markers in non-small cell lung cancer. Oncotarget. 2018; 9:1760-71. https://doi.org/10.18632/oncotarget.18880.

48. Jang TJ. Progressive Increase of Regulatory T Cells and Decrease of CD8+ T Cells and CD8+ T Cells/Regulatory $\mathrm{T}$ Cells Ratio during Colorectal Cancer Development. Korean J Pathol. 2013; 47:443-51. https://doi.org/10.4132/ KoreanJPathol.2013.47.5.443.

49. Maxson ME, Grinstein S. The vacuolar-type $\mathrm{H}(+)$-ATPase at a glance - more than a proton pump. J Cell Sci. 2014; 127:4987-93. https://doi.org/10.1242/jcs.158550.

50. Pamarthy S, Jaiswal MK, Kulshreshtha A, Katara GK, Gilman-Sachs A, Beaman KD. The Vacuolar ATPase a2-subunit regulates Notch signaling in triple-negative breast cancer cells. Oncotarget. 2015; 6:34206-20. https:// doi.org/10.18632/oncotarget.5275.

51. Klein L, Kyewski B, Allen PM, Hogquist KA. Positive and negative selection of the T cell repertoire: what thymocytes see (and don't see). Nat Rev Immunol. 2014; 14:377-91. https://doi.org/10.1038/nri3667.

52. Swamy M, Pathak S, Grzes KM, Damerow S, Sinclair LV, van Aalten DM, Cantrell DA. Glucose and glutamine fuel protein O-GlcNAcylation to control T cell self-renewal and malignancy. Nat Immunol. 2016; 17:712-20. https://doi. org/10.1038/ni.3439.

53. Pamarthy S, Mao L, Katara GK, Fleetwood S, Kulshreshta A, Gilman-Sachs A, Beaman KD. The V-ATPase a2 isoform controls mammary gland development through Notch and TGF-beta signaling. Cell Death Dis. 2016; 7:e2443. https:// doi.org/10.1038/cddis.2016.347.

54. Bilal MY, Dambaeva S, Kwak-Kim J, Gilman-Sachs A, Beaman KD. A Role for Iodide and Thyroglobulin in Modulating the Function of Human Immune Cells. Front Immunol. 2017; 8:1573. https://doi.org/10.3389/ fimmu.2017.01573. 